\title{
Bromocarbons in the tropical marine boundary layer at the Cape Verde Observatory - measurements and modelling
}

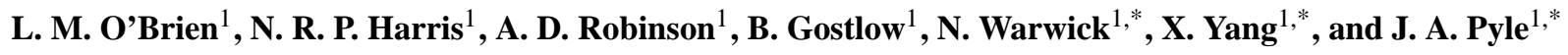 \\ ${ }^{1}$ Centre for Atmospheric Science, Department of Chemistry, University of Cambridge, Lensfield Road, \\ Cambridge, CB2 1EW, UK \\ *also at: National Centre for Atmospheric Science, NCAS-Climate, c/o NCAS Headquarters, School of Earth and \\ Environment, Environment Building, University of Leeds, Leeds, LS2 9JT, UK
}

Received: 2 December 2008 - Published in Atmos. Chem. Phys. Discuss.: 10 February 2009

Revised: 22 June 2009 - Accepted: 14 August 2009 - Published: 30 November 2009

\begin{abstract}
A new gas chromatograph was used to make measurements of halocarbons at the Cape Verde observatory during late May and early June 2007. The instrument demonstrated its potential for long-term autonomous measurements. Bromoform $\left(\mathrm{CHBr}_{3}\right)$ exhibits the most variability of all the halocarbons observed, ranging from a background concentration of about $4 \mathrm{ppt}$ to a maximum of $>40 \mathrm{ppt}$ during the course of the measurement period. $\mathrm{CH}_{2} \mathrm{Br}_{2}$ correlates well with bromoform, suggesting a common regional source. Methyl iodide does not correlate with these bromocarbons, with base levels of around 1-2 ppt and some periods of much higher mixing ratios. Using published bromocarbon emission rates, our chemical transport model studies, presented here, do not reproduce the observations. Local emission magnitudes and $\mathrm{CHBr}_{3}: \mathrm{CH}_{2} \mathrm{Br}_{2}$ ratios must be increased more in line with the recent observations of Yokouchi et al. (2005) to improve the model to measurement comparison. Even when the model reproduces the observed bromocarbons, modelled $\mathrm{BrO}$ is much less than recent tropical observations (Read et al., 2008). A sea salt source seems the likely explanation. When high $\mathrm{BrO}$ is reproduced, the model agrees much better with the observed ozone changes, including diurnal variation, during the measurement period but it is suggested that a representation of iodine chemistry in the model is also required.
\end{abstract}

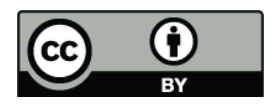

Correspondence to: L. M. O’Brien (lmo29@cam.ac.uk)

\section{Introduction and background}

It is widely accepted that reactive halogen compounds, both of natural and anthropogenic origin, play an important role in controlling the composition of the global atmosphere, and so can also influence climate and local air quality. Stratospheric ozone depletion in recent decades has been driven by the substantial increases in the atmospheric concentrations of a number of anthropogenic halogen compounds. Thus, both chlorine and bromine species are centrally implicated in the large observed ozone destruction in polar regions, as well as in the downward trends in middle latitude ozone. These anthropogenic compounds are now regulated by the Montreal Protocol and their atmospheric abundances have started to decline (see WMO, 2007). However, a number of naturally emitted species are also important for stratospheric ozone chemistry. In particular, it seems that the observed abundance of stratospheric bromine (about $25 \mathrm{ppt}$ ) cannot be explained simply by the breakdown in the stratosphere of methyl bromide, which has natural as well as anthropogenic sources, and the halons (the anthropogenic bromine compounds widely used in fire protection). Additional short-lived bromine compounds, mainly of natural origin, are needed to balance the bromine budget in the lower stratosphere (Pfeilsticker et al., 2000; Dorf et al., 2006; Law and Sturges et al., 2007). In tropical latitudes, deep convection could potentially lift these halogenated species to the upper troposphere/lower stratosphere (UTLS) region, on time scales shorter than the species' lifetime. Photolysis, or oxidation reactions, would then release the active halogen atoms (bromine, but possibly also chlorine and iodine), which could then contribute to stratospheric ozone depletion.

Published by Copernicus Publications on behalf of the European Geosciences Union. 
In contrast to the stratosphere, our understanding of the role of halogens in the global troposphere is still evolving rapidly. It has been clear for some years that brominated compounds are responsible for sporadic, rapid ozone depletion in the polar boundary layer (e.g. Barrie et al., 1988). In the last few years modelling studies by von Glasow et al. (2004) and Yang et al. (2005) have argued that bromine compounds, including both bromocarbons and inorganic salts, can have an important influence on global tropospheric ozone and oxidising capacity. Recent measurements at Cape Verde (Read et al., 2008) show year-round concentrations of reactive $\mathrm{BrO}$ and $\mathrm{IO}$ of several ppt, sufficient to play an important role in controlling local ozone concentrations.

A number of important, unresolved questions relate to the source of the halogens in both tropospheric and stratospheric chemistry. In particular, we need to understand the source processes, their magnitudes, temporal and spatial distributions and variability. Halocarbons have anthropogenic and natural sources with atmospheric lifetimes varying from days to centuries. While we understand the sources and ultimate fate of long-lived halogenated species (such as the man-made CFCs), shorter-lived compounds are still poorly understood in terms of their global fluxes and, as a result, their contributions to the tropospheric and stratospheric ozone budgets are also uncertain. Their short lifetimes of typically days and weeks (compared to, for example, many decades for the major CFCs) mean that it is not straightforward to resolve their global budgets, especially if they might be emitted in highly variable amounts globally; there could, for example, be a number of "hot spot" emission regions.

Recently, attention has focused particularly on the naturally emitted bromine- and iodine-containing compounds (for example see Bassford et al., 1999; Chuck et al., 2005; Salawitch, 2006; von Glasow et al., 2004 and Yokouchi et al., 2005). Short-lived brominated and iodinated halocarbons are known sources of $\mathrm{BrO}$ and $\mathrm{IO}$ radicals to the atmosphere (Yang et al., 2005); bromine and iodine are more efficient than chlorine at destroying stratospheric ozone (e.g. Chipperfield and Pyle, 1998). Bromoform $\left(\mathrm{CHBr}_{3}\right)$ is the major natural contributor of organic bromine to the atmosphere (Penkett et al., 1985; Carpenter and Liss, 2000); it is predominantly oceanic in origin, with tropical macroalgae constituting an important source. An open ocean source, related to phytoplankton, has also been identified (Tokarczyk and Moore, 1994). Other important biogenic compounds of marine origin include dibromomethane $\left(\mathrm{CH}_{2} \mathrm{Br}_{2}\right)$, dibromochloromethane $\left(\mathrm{CHBr}_{2} \mathrm{Cl}\right)$ and iodine-containing species such as methyl iodide $\left(\mathrm{CH}_{3} \mathrm{I}\right)$. Carpenter and Liss (2000) provide an extensive list of red, green and brown macroalgae, which have been suggested as sources of halocarbons for the atmosphere. Important macroalgae species identified as potentially important sources of $\mathrm{CHBr}_{3}$ (and perhaps other brominated species and $\mathrm{CH}_{3} \mathrm{I}$ ) by Moore and Tokarczyk (1993) include Ascophyllum nodosum (with Elachista fuci- culoa growing as an epiphyte) and Fucus vesiculosus. They suggested (see also Norton and Mathieson, 1983) that freefloating macroalgae provide a source of halogenated compounds such as $\mathrm{CHBr}_{3}$. Fucales sargassum and Laminares laminariales were two species of brown macroalgae investigated by Class and Ballschmiter (1988); the main compounds associated with the former were $\mathrm{CH}_{2} \mathrm{Br}_{2}, \mathrm{CHBr}_{3}$, $\mathrm{CHBr}_{2} \mathrm{Cl}, \mathrm{CHBrCl}_{2}$ and $\mathrm{CH}_{2} \mathrm{I}_{2}$. While macroalgae have been identified as an important direct source for the various bromochloromethanes, halogen-exchange reactions, e.g. $\mathrm{CHBr}_{3}+\mathrm{Cl}^{-} \rightarrow \mathrm{CHBr}_{2} \mathrm{Cl}+\mathrm{Br}^{-}$, may constitute a secondary source for certain species (Class and Ballschmiter, 1988). In addition to the bromocarbons, sea salt is an extremely important source of bromine, especially to the marine boundary layer (Kritz and Rancher, 1980; Sander et al., 2003).

Iodine compounds are thought to have a different marine source to the chlorinated and brominated species. Laminaria digitata is an Atlantic giant kelp species which has a very large iodine content and is thus recognised as an important source of $\mathrm{CH}_{3} \mathrm{I}$ (e.g. Grose et al., 2007). Like $\mathrm{CHBr}_{3}, \mathrm{CH}_{3} \mathrm{I}$ may also be emitted in the open ocean from phytoplankton (Moore and Tokarczyk, 1993; Moore et al., 1996); such a source provides a smaller flux rate than from macroalgae, but a significant global flux owing to the large area of open ocean (Grose et al., 2007).

The short-lived biogenic halocarbons have been measured in very variable concentrations in a number of different locations, emphasizing the importance of localized emissions of these compounds, which show both temporal and spatial variability. With a lifetime with respect to photolysis and reaction with hydroxyl $(\mathrm{OH})$ radicals of two to three weeks (Warwick et al., 2006), $\mathrm{CHBr}_{3}$ exhibits large spatial variability. For example, a study by Carpenter et al. (2007) measured $\mathrm{CHBr}_{3}$ concentrations over the eastern Atlantic Ocean between $25^{\circ} \mathrm{N}$ and $25^{\circ} \mathrm{S}$, ranging from a minimum of $0.2 \mathrm{ppt}$ to a maximum of $13.3 \mathrm{ppt}$ at $9.5^{\circ} \mathrm{N}$. Similar maximum mixing ratios of $\mathrm{CHBr}_{3}$ over the tropical northern Atlantic Ocean were observed by Class and Ballschmiter (1988) (14 ppt) and Quack et al. (2004) (25 ppt). In the eastern Atlantic Ocean, the bioactive Mauritanian upwelling has been suggested as an important source of reactive organic bromine (Quack et al., 2007a; Carpenter et al., 2007), though ship-borne measurements taken in May/June 2007 found no instances of high atmospheric $\mathrm{CH}_{2} \mathrm{Br}_{2}$ or $\mathrm{CHBr}_{3}$ concentrations (Carpenter et al., 2009). Quack et al. (2007b) found that their atmospheric measurements over the tropical North Atlantic Ocean could not be explained solely by emissions from the Mauritanian upwelling and suggested that a West African continental source was necessary.

Shallow coastal areas seem to be particularly important for emissions of oceanic halocarbons. Yokouchi et al. (2005) observed a maximum of 40 ppt of $\mathrm{CHBr}_{3}$ at the coast on San Cristobal Island in the tropical Pacific Ocean, with similar concentrations being measured at a coastal site on Christmas Island, also in the tropical Pacific Ocean. The highest 
concentrations of polybromomethanes coincided with the onshore sea breeze, across the coastal zone. Several studies have also shown $\mathrm{CHBr}_{3}$ and $\mathrm{CH}_{2} \mathrm{Br}_{2}$ to be well correlated in coastal locations, suggesting a common source for these compounds (for example see Quack et al., 2007b; Yokouchi et al., 2005). Yokouchi et al. (2005) found that correlations amongst these compounds were weak or absent for open ocean samples over the Pacific Ocean, as well as for an inland site on Java Island; concentrations were also much lower than those for coastal sites. Air samples taken along the coastlines of islands (Bermuda, Sao Miguel and Tenerife) by Class and Ballschmiter (1988) revealed concentrations of up to $200 \mathrm{ppt}$ for $\mathrm{CHBr}_{3}$ and $25 \mathrm{ppt}$ for $\mathrm{CH}_{2} \mathrm{Br}_{2}$. Moving to even more local scales, Ekdahl et al. (1998) presented extremely high atmospheric concentrations of $\mathrm{CHBr}_{3}$ from a rock pool (with no tidal influences during sampling) on the island of Gran Canaria in the Atlantic Ocean (2000-26000 ppt range). High concentrations of other halogenated species were also measured during this study (e.g. $\mathrm{CH}_{2} \mathrm{Br}_{2}$ (37-340 ppt), $\mathrm{CH}_{3} \mathrm{I}$ (24-84 ppt) and $\mathrm{CHBr}_{2} \mathrm{Cl}$ (19 to $\left.130 \mathrm{ppt}\right)$ ).

Bromocarbon measurements at the coast often show significant correlations, consistent with a common oceanic source. Yokouchi et al. (2005) (see also Carpenter et al., 2003) have exploited the correlations to explore the possible source strengths of the individual species, following McKeen and Liu (1993). For example, a plot of $\mathrm{CH}_{2} \mathrm{Br}_{2} / \mathrm{CHBr}_{3}$ versus $\mathrm{CHBr}_{3}$ often shows a straight line behaviour with the ratio $\mathrm{CH}_{2} \mathrm{Br}_{2} / \mathrm{CHBr}_{3}$ increasing with decreasing $\mathrm{CHBr}_{3}$. Bromoform is the shorter-lived of the two species, so an increase in the ratio would be consistent with more aged air masses, in which bromoform has been preferentially removed. Alternatively, the change in ratio is also consistent with dilution of the original air mass into a background with higher $\mathrm{CH}_{2} \mathrm{Br}_{2}$ (a likely situation since $\mathrm{CH}_{2} \mathrm{Br}_{2}$ is longer lived). In either case, the smallest ratio of $\mathrm{CH}_{2} \mathrm{Br}_{2} / \mathrm{CHBr}_{3}$ measured is most consistent with some constant initial emission ratio, since neither mixing nor chemistry can reduce the ratio further. Assuming that the emissions have common sources and are constant on a regional scale, Yokouchi et al. (2005) use this minimum ratio to define the ratio of the emission sources. When more bromocarbons are measured, a plot of $\mathrm{CHBr}_{3} / \mathrm{CH}_{2} \mathrm{Br}_{2}$ versus, say, $\mathrm{CHBr}_{2} \mathrm{Cl} / \mathrm{CH}_{2} \mathrm{Br}_{2}$, where $\mathrm{CH}_{2} \mathrm{Br}_{2}$ has the longest lifetime, can also be used, following McKeen and Liu (1993), to derive emission ratios. In this case the data form a triangle, two of whose sides are defined by a "dilution line" (the 1:1 slope for mixing into a zero background) and a "chemical decay line", defined by the lifetimes of the species. The sides should intersect at a point, which defines the emission ratios.

Global emission magnitudes and distributions for the short-lived oceanic bromocarbons are not well constrained due to their high geographical and temporal variability. Emission estimates for bromoform are particularly uncertain and estimates from a variety of studies range from $200 \mathrm{Gg} \mathrm{Br} \mathrm{yr}^{-1}$ to over $1000 \mathrm{Gg} \mathrm{Br} \mathrm{yr}^{-1}$ (e.g. Kurylo and Ro- driguez, 1999; Penkett et al., 1985; Butler et al., 2007). Global emissions for the other oceanic bromocarbons are less well studied. WMO (2003) recommended emission values for $\mathrm{CHBr}_{3}, \mathrm{CH}_{2} \mathrm{Br}_{2}$ and $\mathrm{CHBr}_{2} \mathrm{Cl}$ of 209,61 and $8 \mathrm{Gg} \mathrm{Br} \mathrm{yr}^{-1}$ respectively, based on estimates of global burdens and local lifetimes (calculated using an $\mathrm{OH}$ concentration of $10^{6} \mathrm{~cm}^{-3}$ and a globally and seasonally averaged photolysis constant). The more detailed 3-D model study by Warwick et al. (2006) assumed the emissions of these compounds were predominantly situated in the tropics. They therefore calculated lower global lifetimes due to higher $\mathrm{OH}$ concentrations and solar radiation in this region, requiring higher emissions to reproduce atmospheric observations. The Warwick et al. (2006) emission estimates for $\mathrm{CHBr}_{3}, \mathrm{CH}_{2} \mathrm{Br}_{2}$ and $\mathrm{CHBr}_{2} \mathrm{Cl}$ were 565, 104 and $18 \mathrm{Gg} \mathrm{Br} \mathrm{yr}^{-1}$ respectively, significantly larger than the WMO (2003) estimates. Bottom-up studies based on global extrapolations of local fluxes also produced relatively high global emission estimates of 780 and $800 \mathrm{Gg} \mathrm{Br} \mathrm{yr}^{-1}$ for $\mathrm{CHBr}_{3}$ and $280 \mathrm{Gg} \mathrm{Br} \mathrm{yr}^{-1}$ for $\mathrm{CH}_{2} \mathrm{Br}_{2}$ (Quack and Wallace, 2003; Butler et al., 2007). Yokouchi et al. (2005) calculated a $\mathrm{CHBr}_{3}: \mathrm{CH}_{2} \mathrm{Br}_{2}: \mathrm{CHBr}_{2} \mathrm{Cl}$ emission ratio of 9:1:0.7 and obtained global emission estimates for $\mathrm{CHBr}_{3}$ and $\mathrm{CHBr}_{2} \mathrm{Cl}$ of 820 and $43 \mathrm{Gg} \mathrm{Br} \mathrm{yr}^{-1}$, using the relatively low WMO (2003) $\mathrm{CH}_{2} \mathrm{Br}_{2}$ emission value.

In this work, we report measurements made at the Cape Verde Atmospheric Observatory using $\mu$-Dirac, our gas chromatograph with electron capture detector (GC-ECD). $\mu$ Dirac is the latest version (Gostlow et al., 2009) of the Dirac instrument, which measures a range of halocarbons (Robinson et al., 2000, 2005). The new version is purpose-built and relatively inexpensive, being designed to make long-term measurements of a small number of halocarbons. Its relatively low cost and ease of operation mean that the instrument can be deployed at a number of surface sites, thereby providing a valuable constraint on variability and emission estimates. Two instruments were deployed at Cape Verde in May and June 2007, during an intensive field campaign. They were optimised for the measurement of a number of the short-lived compounds mentioned above, allowing measurements of $\mathrm{CHBr}_{3}, \mathrm{CH}_{2} \mathrm{Br}_{2}, \mathrm{CHCl}_{2} \mathrm{Br}, \mathrm{CH}_{3} \mathrm{I}$ and $\mathrm{C}_{2} \mathrm{Cl}_{4}$, plus a number of longer-lived species. Our objectives here are threefold: to present the measurement series; to explore the implications for emissions and to investigate the role of the measured compounds in controlling local oxidizing capacity. In Sect. 2 we introduce the experimental and modelling tools used, followed in Sect. 3 by a discussion of the prevailing meteorological conditions. The Cape Verde groundbased measurements are presented in Sect. 4.1. The data are interpreted in Sect. 4.2, first by studying the correlations, following Yokouchi et al. (2005), and second using our chemical transport model, p-TOMCAT. p-TOMCAT is also used in Sect. 4.3 to investigate the implications of our measurements for tropospheric ozone. Findings are summarised in Sect. 5. 


\section{Experimental details}

\subsection{The Cape Verde Observatory}

The Cape Verde Atmospheric Observatory is a recently established monitoring site, situated at $16.8^{\circ} \mathrm{N}, 24.9^{\circ} \mathrm{W}$ on the island of Sao Vicente, Cape Verde. It is an ideal site for sampling "background" air within the tropical Atlantic marine boundary layer. A 3-week intensive field campaign, part of the NERC SOLAS/RHaMBLe project, took place in May/June 2007 in and around the Cape Verde islands (see Read et al., 2008). A large range of ground-based, aircraft and ship-borne instruments were deployed, to complement the long-term measurements that have been established at the observatory (http://www.york.ac.uk/capeverde/). Using $\mu$-Dirac, gas chromatographic measurements of a variety of halocarbons with a range of lifetimes and sources were made at the observatory during the 3 -week intensive. These were complemented by a set of $\mu$-Dirac aircraft measurements made on board the NERC ARSF Dornier 228-101 research aircraft, which made a number of flights in the tropical marine boundary layer and lower troposphere of the surrounding area. Only the ground-based measurements are dealt with in this paper (see the BADC website for the Dornier data; http://badc.nerc.ac.uk/data/solas/).

\subsection{The $\mu$-Dirac gas chromatograph}

$\mu$-Dirac is a custom-built GC-ECD, which makes in situ measurements of halocarbons (Gostlow et al., 2009). It was originally designed for flights on long duration balloons and so is lightweight and able to operate autonomously for several weeks. Earlier versions have been deployed on balloons, at ground-based sites and on aircraft (Robinson et al., 2000, 2005; Ross et al., 2004). $\mu$-Dirac is well suited for long periods of unattended operation. It has a modular design with an adsorbent-containing micro-trap, which removes the halocarbons from the air. A fixed volume of $20 \mathrm{scc}$ is collected for each atmospheric sample, with a sampling time of approximately $1.5 \mathrm{~min}$. The micro-trap is then flash heated and the desorbed halocarbons are passed through a chromatographic column with temperature and flow programming capability. After temporal separation in the column the flow passes through the ECD, which is extremely sensitive to halocarbons. Instrument control and data collection are achieved using an on-board microcontroller.

During the Cape Verde deployment, the instrument was housed in an air-conditioned container, with the inlet fixed outside at a height of approximately 10 metres. The run cycle was roughly $14 \mathrm{~min}$, with a blank sample and a calibration standard being sampled on average after ten atmospheric samples (i.e. every 2 to $3 \mathrm{~h}$ ). The instrument was cooled internally with Peltier coolers. The species that are measured include: CFC-11, CFC-113, $\mathrm{CH}_{3} \mathrm{CCl}_{3}, \mathrm{CCl}_{4}, \mathrm{CH}_{3} \mathrm{I}, \mathrm{CH}_{2} \mathrm{Cl}_{2}$, $\mathrm{C}_{2} \mathrm{HCl}_{3}, \mathrm{CHCl}_{2} \mathrm{Br} / \mathrm{CH}_{2} \mathrm{Br}_{2}, \mathrm{C}_{2} \mathrm{Cl}_{4}$, and $\mathrm{CHBr}_{3}$. In this pa- per we report results for $\mathrm{C}_{2} \mathrm{Cl}_{4}, \mathrm{CHCl}_{3}, \mathrm{CH}_{3} \mathrm{I}, \mathrm{CH}_{2} \mathrm{Br}_{2}$, $\mathrm{CHBr}_{2} \mathrm{Cl}$ and $\mathrm{CHBr}_{3}$. Their measurement characteristics are given in Table 1.

The absolute calibration for most of the reported gases is determined by reference to a NOAA-ESRL calibration standard (certified in December 2005), with an on-board standard gas bottle being filled directly with air from the NOAAESRL standard. The one exception is $\mathrm{CHBr}_{2} \mathrm{Cl}$, which is discussed below. The on-board standard lasted for the duration of the campaign. $20 \mathrm{scc}$ samples of the NOAA-ESRL calibration standard gas were measured every 2 to $3 \mathrm{~h}$ assuring a direct link to that scale. Calibration between groups is an important issue and there are discrepancies between our measurements and preliminary measurements made during the campaign at the same site by the University of Bristol (S. O'Doherty, personal communication, 2008). The $\mu$-Dirac measurements of, for example, $\mathrm{CH}_{3} \mathrm{CCl}_{3}$ are in agreement with concurrent measurements from the NOAA-ESRL and AGAGE networks, indicating that any problems are related to specific gases. We are taking part in an international comparison of VSLH calibration scales performed within the SOLAS/IGAC initiative HitT.

No calibration standard for $\mathrm{CHBr}_{2} \mathrm{Cl}$ was available during this deployment, although it was detectable in the NOAAESRL calibration gas. Here we use the ratio of this peak to that of $\mathrm{CH}_{2} \mathrm{Br}_{2}$ in the calibration gas to estimate the calibration concentration. The ECD responses for the molecules are dominated by the two bromine atoms, suggesting similar sensitivities for the two species. In this case, the ratio of the calibration signals would be the same as the ratio of the concentrations in the calibration gas. With 4.8 ppt of $\mathrm{CH}_{2} \mathrm{Br}_{2}$ in the calibration gas, we estimate that the standard contained 0.19 ppt of $\mathrm{CHBr}_{2} \mathrm{Cl}$. Clearly, the absolute accuracy of our determination of $\mathrm{CHBr}_{2} \mathrm{Cl}$ is low and we estimate this as $50 \%$ in Table 1. However the precision is relatively good (9.6\%, see Table 1) and it is thus safe to investigate its variability during the measurement period and its correlation with other species.

The peaks for $\mathrm{CHBrCl}_{2}$ and $\mathrm{CH}_{2} \mathrm{Br}_{2}$ currently overlap, each having a retention time of about $5.1 \mathrm{~min}$. Examination of a small subset of chromatograms taken in Cape Verde suggests that $\mathrm{CHBrCl}_{2}$ was present only in small quantities. However, for the majority of our chromatograms, it was not possible to resolve the two peaks, owing to their nearly identical retention times. The ECD response depends on the electron-capture coefficient, which represents the degree to which the compound is able to capture thermal electrons (see, e.g., Lovelock, 1961; Dressler, 1986). In our laboratory it has not yet been possible to determine ECD response factors for each of these compounds (due to the coelution problem we would require a known concentration of each compound exclusively in separate cylinders). However, Class and Ballschmiter (1986) determined the response factors for an $\mathrm{ECD}$ relative to $\mathrm{CCl}_{4}$ for several compounds, and they found that the relative response factors for $\mathrm{CHBrCl}_{2}$ 
Table 1. Measurement characteristics during the Cape Verde deployment of $\mu$-Dirac. The precisions are the single standard deviations (in \%) of the measurements of the calibration standards. The accuracies for $\mathrm{CH}_{3} \mathrm{I}, \mathrm{CH}_{2} \mathrm{Br}_{2}, \mathrm{CHBr}_{3}, \mathrm{C}_{2} \mathrm{Cl}_{4}$, and $\mathrm{CHCl}_{3}$ are taken from the values quoted with the NOAA-ESRL supplied standard. We report the combined peak $\left(\left[\mathrm{CH}_{2} \mathrm{Br}_{2}\right]+\left[\mathrm{CHBrCl}_{2}\right]\right)$ as simply $\left[\mathrm{CH}_{2} \mathrm{Br}_{2}\right]$; as a result we acknowledge an uncertainty in our $\mathrm{CH}_{2} \mathrm{Br}_{2}$ measurement of between 10 and $30 \%$. The accuracy for $\mathrm{CHBr}_{2} \mathrm{Cl}$ is estimated as $50 \%$ since no value is available for the amount in the calibration standard (see text). The detection limits are estimated from the signal to noise ratio (average calibration peak height/RMS of the noise level, blank samples), using the known amount of a compound in the calibration gas to deduce the smallest detectable concentration. See Gostlow et al. (2009) for more details.

\begin{tabular}{lllllll}
\hline Species & $\mathrm{CH}_{3} \mathrm{I}$ & $\mathrm{CH}_{2} \mathrm{Br}_{2}$ & $\mathrm{CHBr}_{3}$ & $\mathrm{C}_{2} \mathrm{Cl}_{4}$ & $\mathrm{CHCl}_{3}$ & $\mathrm{CHBr}_{2} \mathrm{Cl}$ \\
\hline Precision & $8.4 \%$ & $4 \%$ & $3.2 \%$ & $1.6 \%$ & $1.4 \%$ & $9.6 \%$ \\
Accuracy & $3 \%$ & $2.1 \%$ & $2.2 \%$ & $3 \%$ & $1 \%$ & $50 \%$ \\
$\begin{array}{l}\text { Detection } \\
\text { limit }\end{array}$ & $0.3 \mathrm{ppt}$ & $0.1 \mathrm{ppt}$ & $0.4 \mathrm{ppt}$ & $0.2 \mathrm{ppt}$ & $0.7 \mathrm{ppt}$ & $0.02 \mathrm{ppt}$ \\
\hline
\end{tabular}

and $\mathrm{CH}_{2} \mathrm{Br}_{2}$ were similar, being 0.6 and 0.5 , respectively. However the atmospheric $\mathrm{CHBrCl}_{2}$ concentrations are usually less than those of $\mathrm{CH}_{2} \mathrm{Br}_{2}$. Class et al. (1986) found that the ratio of $\mathrm{CHBrCl}_{2}: \mathrm{CH}_{2} \mathrm{Br}_{2}$ concentrations in North Atlantic marine air range from 0.11 to 0.33 with a mean of 0.18 . A similar conclusion was reached by Schall et al. (1997). In summary, for reasons of chromatographic sensitivity and expected atmospheric abundances, we report the combined peak $\left(\left[\mathrm{CH}_{2} \mathrm{Br}_{2}\right]+\left[\mathrm{CHBrCl}_{2}\right]\right)$ as simply $\left[\mathrm{CH}_{2} \mathrm{Br}_{2}\right]$. Based on the response factors of Class et al. (1988), this would imply that we are overestimating $\mathrm{CH}_{2} \mathrm{Br}_{2}$ by 10 to $30 \%$. We choose to acknowledge the uncertainty rather than to make a correction since any correction would be different for each measurement.

\subsection{The model}

We use the p-TOMCAT chemical transport model to complement our halocarbon measurements. In particular, we use the model to investigate whether the measurements are consistent with proposed emissions and, if not, ask what emissions are required. We also use the model to look at the impact of the halocarbons on the local ozone at Cape Verde. In this section we describe the important features of the model for these studies and then summarise the simulations that have been performed.

The basic formulation of the global chemistry and transport model p-TOMCAT is described in Law et al. (2000) and Savage et al. (2004). Here we base the model on a version of p-TOMCAT described by Yang et al. (2005) which includes a detailed description of tropospheric bromine chemistry, including emissions of bromocarbons $\left(\mathrm{CH}_{3} \mathrm{Br}, \mathrm{CHBr}_{3}\right.$, $\mathrm{CH}_{2} \mathrm{Br}_{2}, \mathrm{CH}_{2} \mathrm{BrCl}, \mathrm{CHBr} 2 \mathrm{Cl}$ and $\mathrm{CHBrCl}_{2}$ ) from Warwick et al. (2006) and a treatment of the inorganic sea salt source from the open ocean. The bromine chemistry scheme contains both gas-phase reactions and heterogeneous reactions on cloud particles and background aerosols. A total of 13 bromine-containing compounds are considered in the model: 7 inorganic compounds $\left(\mathrm{Br}, \mathrm{Br}_{2}, \mathrm{BrO}, \mathrm{HOBr}, \mathrm{BrONO}_{2}\right.$, $\mathrm{BrNO}_{2}$ and $\mathrm{HBr}$ ) and the 6 emitted organic compounds. Here, the model is improved (see Yang et al., 2008) by considering a size dependent bromine depletion factor to describe the bromine release from sea salt aerosols (rather than the constant value used in our earlier study), as well as a third atmospheric bromine source coming from blowing snow on sea ice (although the latter, of course, has modest immediate impact in the tropics). The bromine chemistry scheme has also been updated by adding 3 further heterogeneous reactions to reactivate inactive gaseous species, including $\mathrm{HBr}$, to active forms, such as $\mathrm{BrO}$ (Yang et al., 2009). The model does not include a scheme for active iodine chemistry. However, in order to compare with our observations, surface emissions of $\mathrm{CH}_{3} \mathrm{I}$ and loss via photolysis and reaction with $\mathrm{OH}$ have been added.

Emission datasets for the oceanic bromocarbons are from Warwick et al. (2006), Scenario B. The geographical distribution consists of a band of emissions in the tropical open ocean $\left(20^{\circ} \mathrm{N}-20^{\circ} \mathrm{S}\right)$, with bands of weaker emissions in northern and southern mid-latitudes $\left(20-50^{\circ}\right)$. For bromoform, the dataset also includes increased emissions along tropical coastlines $\left(10^{\circ} \mathrm{N}-10^{\circ} \mathrm{S}\right)$. These emissions are aseasonal.

In this study, p-TOMCAT was run with a $2.8^{\circ} \times 2.8^{\circ}$ horizontal resolution, with 31 vertical levels from the surface to $10 \mathrm{hPa}$. The offline meteorological fields used are from the European Medium Range Weather Forecast reanalysis data, updated every $6 \mathrm{~h}$. We focus here on a period from late May to mid June 2007. All the runs performed are based on a spun-up integration which covers this period. For descriptions of other physical parameterisations see Cook et al. (2007).

We have performed a number of calculations with pTOMCAT. These include a run without bromine chemistry $(\mathrm{NoBr})$; a base run (MON) with a halocarbon emission distribution based on Warwick et al. (2006) and using the Monahan et al. (1986) sea salt source, as presented previously by Yang et al. (2005); a run with elevated bromocarbon emissions across the region from $10-20^{\circ} \mathrm{N}$ and $20-30^{\circ} \mathrm{W}(\mathrm{HiBr})$, covering several model grid boxes surrounding Cape Verde. In $\mathrm{HiBr}$ the elevated emissions were only included during the daytime; there were no night time emissions in the selected region. During the day the elevated emissions were a factor of 20 higher than in MON. Org is a run using the same emissions as $\mathrm{HiBr}$ but without the sea salt source. Finally, HiSALT includes a substantial increase in sea salt bromine over the same region. Table 2 summarises the various model runs and their bromine emission scenarios from halocarbon and sea salt sources. 
Table 2. A description of bromine emissions from halocarbons and sea salt aerosol used in the 5 model scenarios.

\begin{tabular}{|c|c|c|}
\hline Emission Scenario & Br Flux from halocarbons & Br Flux from sea salt \\
\hline MON & $\begin{array}{l}\text { Warwick et al. (2006), Scenario B } \\
\text { (with a total of } 808 \mathrm{Gg} \mathrm{Br} / \mathrm{yr} \text {, } \\
\text { of which } 564 \mathrm{Gg} \mathrm{Br} / \mathrm{yr} \text { is } \\
\text { from } \mathrm{CHBr}_{3} \text { ) }\end{array}$ & Monahan et al. (1986) \\
\hline $\mathrm{NoBr}$ & Zero & Zero \\
\hline $\mathrm{HiBr}$ & $\begin{array}{l}\text { As MON, but with elevated } \\
\mathrm{CHBr}_{3} \text { and } \mathrm{CH}_{2} \mathrm{Br}_{2} \text { emissions } \\
\text { from } 10-20^{\circ} \mathrm{N} \text { and } 20-30^{\circ} \mathrm{W} \\
\text { (see text) }\end{array}$ & Monahan et al. (1986) \\
\hline Org & As $\mathrm{HiBr}$ & Zero \\
\hline HiSALT & As $\mathrm{HiBr}$ & $\begin{array}{l}\text { As MON, but using a higher flux } \\
\text { from } 10-20^{\circ} \mathrm{N} \text { and } 20-30^{\circ} \mathrm{W}, \\
\text { corresponding to a high } \\
\text { windspeed of } 13 \mathrm{~ms}^{-1} \text { (see text) }\end{array}$ \\
\hline
\end{tabular}

We have also performed a number of sensitivity experiments, varying slightly the geographical region with the elevated bromine emissions (i.e., sensitivity experiments based on $\mathrm{HiBr}$ ). These are also mentioned below.

\section{Overview of meteorological conditions}

For the duration of the measurement period, the Cape Verde islands were generally under the influence of a region of Atlantic high pressure. Typically, the mean sea level pressure at the site was fairly constant at around $1015 \mathrm{hPa}$. The $\mu$-Dirac measurement period lasted from 30 May until 15 June 2007 (with a few short breaks in the data due to technical problems at the site). The measurement site was characterised by a very stable boundary layer, whose depth of about $1000 \mathrm{~m}$ was roughly constant during the course of the campaign; a strong temperature inversion of up to $10^{\circ} \mathrm{C}$ separated this marine boundary layer from the free troposphere above. Local wind speeds ranged from about $2 \mathrm{~ms}^{-1}$ to $12 \mathrm{~ms}^{-1}$ over the measurement period. Consistent with the position of the Azores high, the wind direction ranged from about 10 to $80^{\circ}$; generally it was about $50^{\circ}$ (i.e. flow dominated by north-easterlies). A period of generally decreasing wind speeds was observed from 5 to 8 June, with wind speeds reaching a minimum of about $2 \mathrm{~ms}^{-1}$ by 8 June. Wind speeds then increased generally during 9 and 10 June. The wind speeds reached a maximum during the day (see http://www.york.ac.uk/capeverde/).

Figure 1 shows typical trajectories obtained from the British Atmospheric Data Centre (http://badc.nerc.ac.uk/ home/index.html), arriving at $950 \mathrm{hPa}$ at Cape Verde on 25 May and 5, 7 and 15 June 2007. All the trajectories are char- acterised by flow around the Azores anticyclone. For 25 May, the air parcels have travelled predominantly over the ocean, while for 5 and 7 June they have spent time over the Iberian Peninsula and then travelled parallel to the West African coast, passing the Canary Islands. For 15 June, air parcels pass directly over the West African coast; this was the only day when this occurred. In all cases, the air parcels spent time in the boundary layer prior to arrival at Cape Verde.

\section{Results}

In Sect. 4.1 we present first the halocarbon observations made at Cape Verde and discuss the correlations between individual halocarbons. Interpretation of the data is given in Sect. 4.2, firstly by using the correlation plots and secondly using our CTM. Section 4.3 discusses the implications of our measurements for tropospheric ozone.

\subsection{Observations from the Cape Verde Observatory}

Figure 2 presents the concentration time series for the period from late May until 15 June 2007. Measurements for $\mathrm{CHBr}_{3}$, $\mathrm{CH}_{3} \mathrm{I}, \mathrm{CH}_{2} \mathrm{Br}_{2}, \mathrm{CHBr}_{2} \mathrm{Cl}, \mathrm{CHCl}_{3}$ and $\mathrm{C}_{2} \mathrm{Cl}_{4}$ are shown. This data is also summarised in Table 3 , which shows minimum, maximum and mean mixing ratios for a selection of halocarbons $\left(\mathrm{CHBr}_{3}, \mathrm{CH}_{2} \mathrm{Br}_{2}, \mathrm{CH}_{3} \mathrm{I}\right.$ and $\left.\mathrm{CHCl}_{3}\right)$ for each day of the measurement period. The periods of missing data are due to power cuts at the observatory.

There is a strong correlation between $\mathrm{CHCl}_{3}$ and $\mathrm{C}_{2} \mathrm{Cl}_{4}$. Figure 3 plots these two species alongside the $\mathrm{CO}$ measurements from the observatory (http://www.york.ac.uk/ capeverde/). All three species correlate well. High mixing ratios are seen on 5 and 6 June when the trajectories indicate 

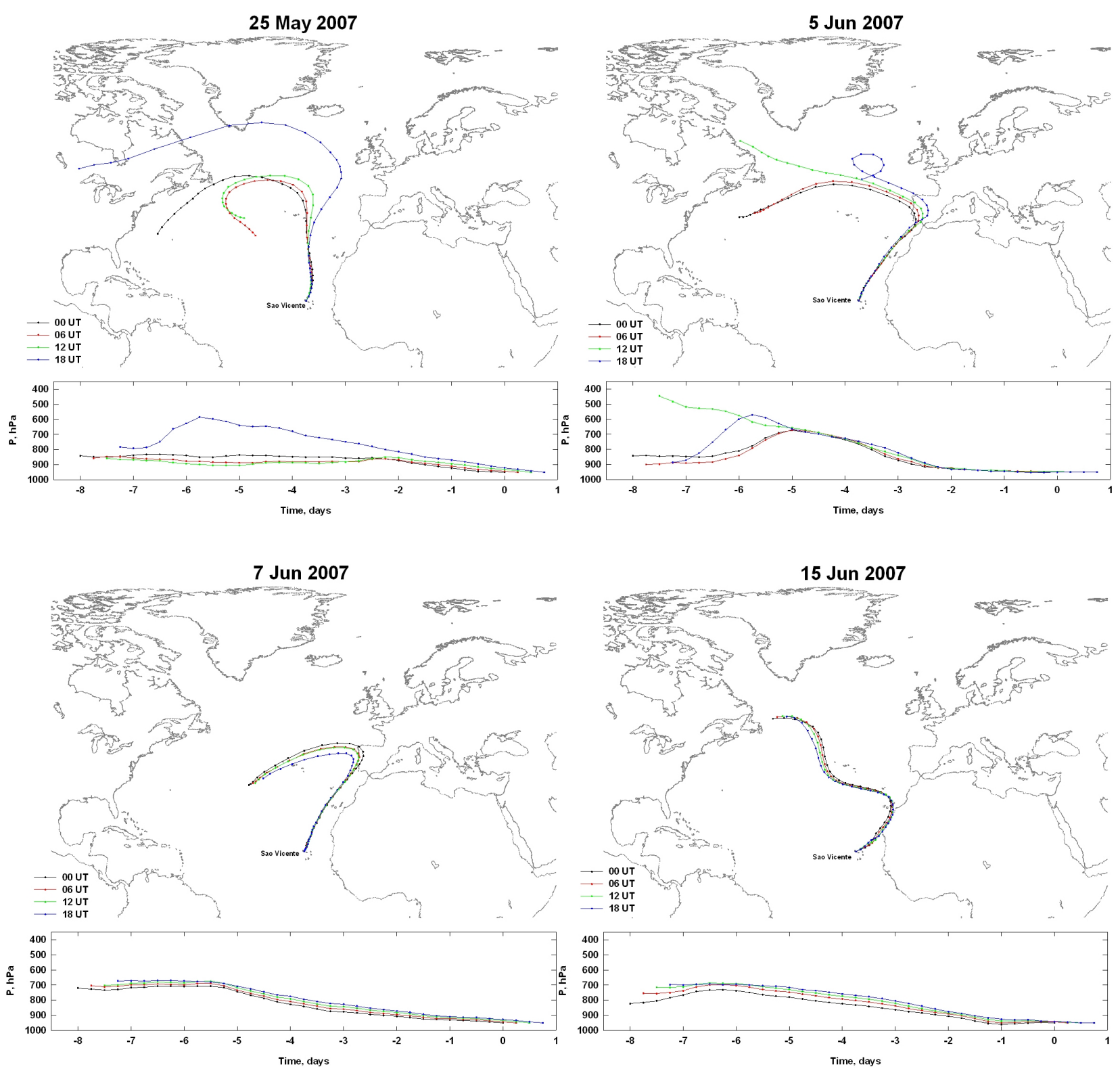

Fig. 1. 8-day back trajectories obtained from the British Atmospheric Data Centre (BADC), shown on a latitude-longitude plot and a pressure-time plot. Trajectories arrive at $950 \mathrm{hPa}$ at the Cape Verde Observatory, Sao Vicente. There are four trajectories per day (at 00:00, 06:00, 12:00 and 18:00 UT).

that the air has previously crossed over Spain and Portugal. On shorter time scales note the decrease in all species late on 9 June. It is clear that, like $\mathrm{CO}, \mathrm{CHCl}_{3}$ and $\mathrm{C}_{2} \mathrm{Cl}_{4}$ are largely anthropogenic. $\mathrm{C}_{2} \mathrm{Cl}_{4}$ is believed to be an exclusively industrial compound and serves as a useful tracer of anthropogenic activity; $\mathrm{CHCl}_{3}$ has both natural and anthropogenic sources. The increases here seem to relate principally to the latter. $\mathrm{C}_{2} \mathrm{Cl}_{4}$ mixing ratios are very low at a few parts per trillion, typical of relatively unpolluted background air which has not been influenced by any major local industrial sources. The other, longer-lived anthropogenic halocarbons $\left(\mathrm{CCl}_{4}, \mathrm{CFCl}_{3}\right.$,
$\mathrm{CH}_{3} \mathrm{CCl}_{3}$, not shown) show little variability during the measurement period.

Bromoform $\left(\mathrm{CHBr}_{3}\right)$ exhibits the most variability of all the halocarbons observed, ranging from a background concentration of about $4 \mathrm{ppt}$ to maxima of $>40 \mathrm{ppt}$ on $7 / 8$ June. Our background measurements are significantly higher than the North Atlantic open ocean measurements (sub ppt) reported by Butler et al. (2007) and Carpenter et al. (2009). The trajectories arriving at Cape Verde during the whole period have passed over regions of high biological productivity, previously identified as potentially important 


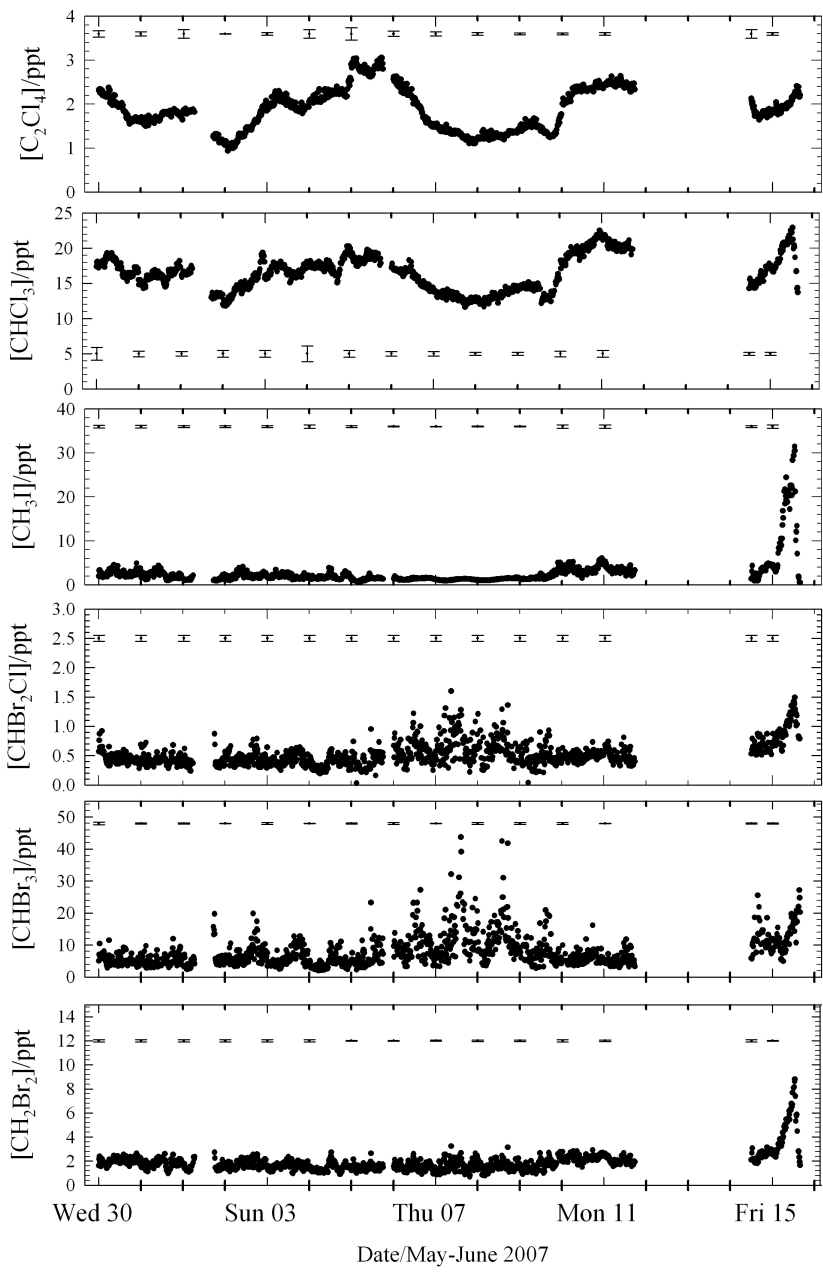

Fig. 2. Time series of $\mathrm{C}_{2} \mathrm{Cl}_{4}, \mathrm{CHCl}_{3}, \mathrm{CH}_{3} \mathrm{I}, \mathrm{CHBr} 2 \mathrm{Cl}, \mathrm{CHBr}_{3}$ and $\mathrm{CH}_{2} \mathrm{Br}_{2}$. The error bars shown are calculated each day. These are $+/-1 \sigma$ error bars and are the precision estimates.

bromocarbon sources for the tropical eastern Atlantic Ocean, and SeaWifs data for June 2007 (http://oceancolor.gsfc. nasa.gov/SeaWiFS/) show maximum Chl- $a$ along the West African coast, extending into the ocean around the Mauritanian upwelling. The air masses sampled around 7/8 June would certainly have been influenced by emissions from the upwelling (see Fig. 1). However, Quack et al. (2007b) argue that other West African sources must also contribute to high measurements reported for the tropical eastern Atlantic region. Our trajectories, with the exception of those for 15 June, do not cross over the African continent.

Two very large $\mathrm{CHBr}_{3}$ peaks, corresponding to the maximum $\mathrm{CHBr}_{3}$ observed during the campaign ( $>40 \mathrm{ppt}$ ), occurred during a period of elevated bromoform concentrations between 7-10 June. Maximum $\mathrm{CHBr}_{3}$ mixing ratios were observed at approximately midday on both 7 and 8 June. Meanwhile, mixing ratios of the anthropogenic species $\left(\mathrm{CHCl}_{3}, \mathrm{C}_{2} \mathrm{Cl}_{4}\right.$ and $\left.\mathrm{CO}\right)$ were some of the lowest observed

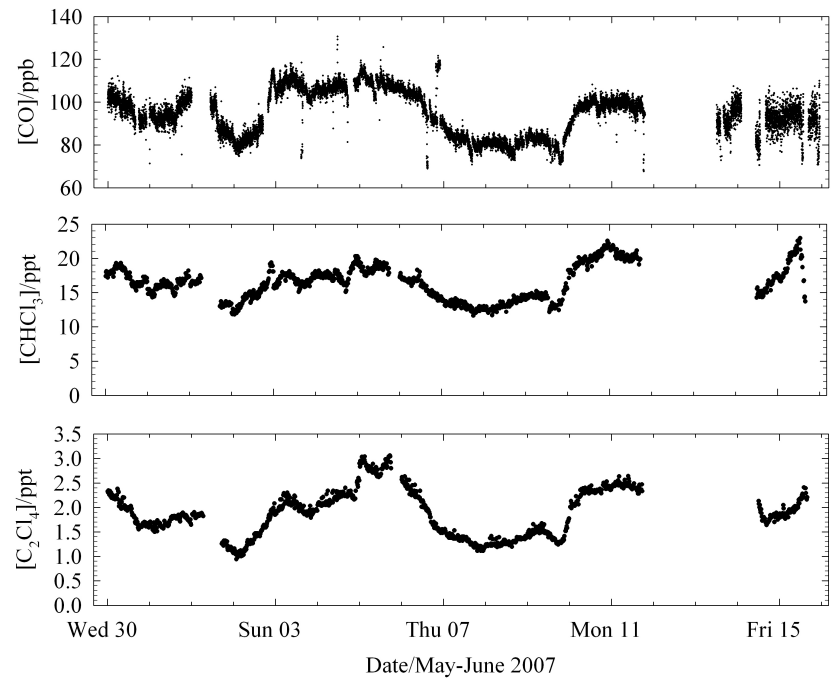

Fig. 3. Time series of CO (data courtesy of University of York), $\mathrm{CHCl}_{3}$ and $\mathrm{C}_{2} \mathrm{Cl}_{4}$.

during the whole campaign, as we have seen in Fig. 3. The very high concentrations and the large amount of scatter in the $\mathrm{CHBr}_{3}$ data suggest that there might be a regional tropical source around the islands contributing to the measurements. For example, the site was directly exposed to the local northeasterly trade winds, which may have transported high levels of $\mathrm{CHBr}_{3}$ from local oceanic sources to the site. We will discuss these possibilities further in Sect. 4.2.2.

Figure 2 shows a good correlation between $\mathrm{CHBr}_{2} \mathrm{Cl}$ and $\mathrm{CHBr}_{3}$, and $\mathrm{CH}_{2} \mathrm{Br}_{2}$ also correlates well with $\mathrm{CHBr}_{3}$ (see Sect. 4.2). Mixing ratios of $\mathrm{CH}_{3} \mathrm{I}$ are generally 1 or $2 \mathrm{ppt}$, but higher peaks in concentration occur on 10, 11 and 15 June. $\mathrm{The} \mathrm{CHBr}_{3}$ data for the period around 7/8 June does not correlate with the $\mathrm{CHBr}_{3}$ data for that same period, suggesting different sources for these compounds. Many of the species, with both anthropogenic and natural sources, show very high concentrations on 15 June. The trajectories (Fig. 1) show that 15 June was the only day where the sampled air masses had passed directly over the coast and could have been affected by West African emissions. This was also the day chosen ahead of time to end the period of autonomous measurement in order to return the instrument to Cambridge, so unfortunately we are unable to say for how long these high concentrations were sustained.

\subsection{Implications for halocarbon emissions}

In this section, we first use the correlation approaches described in Sect. 1 to make some inferences about the emission ratios of halocarbons. We then try to reproduce the observed concentrations using the p-TOMCAT model, considering different emission scenarios. In Sect. 4.3, we then consider implications for the oxidizing capacity of the troposphere. 
Table 3. Summary of selected halocarbon data $\left(\mathrm{CHBr}_{3}, \mathrm{CH}_{2} \mathrm{Br}_{2}, \mathrm{CH}_{3} \mathrm{I}, \mathrm{CHCl}_{3}\right)$ collected at the Cape Verde Observatory from $30 \mathrm{May}$ to 15 June 2007. The range (minimum to maximum) and mean (with standard deviation in brackets) are given, for each of the four species and for each day of the campaign. The number of samples each day was usually more than 80 (with the exception of $1,5,11,14$ and 15 June, which had 55, 65, 65, 41 and 59 samples, respectively).

\begin{tabular}{lllllllll}
\hline & $\mathrm{CHBr}_{3}$ & & $\mathrm{CH}_{2} \mathrm{Br}_{2}$ & & $\mathrm{CH}_{3} \mathrm{I}$ & & \multicolumn{2}{l}{$\mathrm{CHCl}_{3}$} \\
\hline Date & Range & Mean (S.D.) & Range & Mean (S.D.) & Range & Mean (S.D.) & Range & Mean (S.D.) \\
\hline 30-Jun & $2.8-11.5$ & $5.3(1.6)$ & $1.4-2.6$ & $2.0(0.2)$ & $1.7-4.9$ & $2.7(0.7)$ & $15.3-19.3$ & $17.4(1.0)$ \\
31-May & $2.8-11.9$ & $5.2(1.8)$ & $1.0-2.6$ & $1.8(0.3)$ & $1.0-4.4$ & $2.1(0.8)$ & $14.3-18.2$ & $16.0(0.9)$ \\
01-Jun & $2.4-19.7$ & $5.5(3.4)$ & $1.1-2.7$ & $1.6(0.4)$ & $0.9-4.8$ & $1.5(0.7)$ & $12.8-17.5$ & $14.9(1.7)$ \\
02-Jun & $3.3-19.9$ & $6.9(3.2)$ & $1.1-2.6$ & $1.8(0.3)$ & $1.0-4.1$ & $2.1(0.6)$ & $11.8-19.4$ & $14.7(1.9)$ \\
03-Jun & $2.5-12.7$ & $6.0(2.7)$ & $1.0-2.4$ & $1.6(0.3)$ & $1.2-3.4$ & $1.9(0.5)$ & $15.1-18.1$ & $16.8(0.7)$ \\
04-Jun & $2.0-11.1$ & $4.3(2.0)$ & $0.9-2.7$ & $1.4(0.3)$ & $1.2-3.9$ & $1.8(0.6)$ & $15.1-20.3$ & $17.6(1.0)$ \\
05-Jun & $2.3-23.2$ & $6.7(3.6)$ & $1.0-2.7$ & $1.5(0.3)$ & $0.7-2.6$ & $1.3(0.4)$ & $17.4-20.0$ & $18.6(0.6)$ \\
06-Jun & $3.3-27.2$ & $9.8(4.9)$ & $0.9-2.6$ & $1.6(0.3)$ & $1.0-2.0$ & $1.4(0.2)$ & $13.8-18.3$ & $16.0(1.1)$ \\
07-Jun & $3.2-43.7$ & $13.5(8.0)$ & $0.7-3.2$ & $1.6(0.5)$ & $0.9-1.4$ & $1.2(0.1)$ & $11.6-14.2$ & $13.1(0.6)$ \\
08-Jun & $3.5-42.5$ & $12.6(7.0)$ & $0.8-3.1$ & $1.5(0.4)$ & $1.0-1.7$ & $1.3(0.2)$ & $11.7-14.7$ & $13.2(0.7)$ \\
09-Jun & $2.8-20.9$ & $7.8(4.0)$ & $0.9-2.8$ & $1.7(0.5)$ & $1.2-5.0$ & $1.9(0.9)$ & $12.2-16.3$ & $14.2(0.9)$ \\
10-Jun & $3.5-16.1$ & $6.0(1.9)$ & $1.5-2.9$ & $2.3(0.3)$ & $1.5-6.0$ & $3.6(1.0)$ & $17.1-22.5$ & $19.9(1.2)$ \\
11-Jun & $3.0-11.8$ & $5.3(1.9)$ & $1.6-2.7$ & $2.0(0.3)$ & $2.0-5.3$ & $3.3(0.7)$ & $19.1-21.9$ & $20.4(0.6)$ \\
14-Jun & $5.7-25.5$ & $11.8(4.2)$ & $1.8-3.1$ & $2.5(0.3)$ & $0.9-4.9$ & $3.1(1.4)$ & $14.3-17.8$ & $15.8(1.1)$ \\
15-Jun & $4.9-27.2$ & $13.1(5.0)$ & $1.7-8.8$ & $4.6(1.8)$ & $0.5-31.4$ & $13.8(8.9)$ & $13.7-22.9$ & $19.1(2.2)$ \\
\hline
\end{tabular}

\subsubsection{Inferred emission ratios}

Figure 4 shows plots of $\mathrm{CH}_{2} \mathrm{Br}_{2} / \mathrm{CHBr}_{3}$ versus $\mathrm{CHBr}_{3}$ for each individual day from 30 May until 15 June 2007 and for all days combined. There is a good correlation throughout the measurement period. The slope for all data is -0.74 with relatively little daily variation throughout the period (a minimum slope of -0.51 on 7 June and a maximum of -0.96 on 14 June). The data reported in Yokouchi et al. (2005), from the Western Pacific and Christmas Island have a corresponding slope of about -0.76 . The minimum ratio of $\mathrm{CH}_{2} \mathrm{Br}_{2} / \mathrm{CHBr}_{3}$ does vary a little from day to day but is around 0.06 (with values ranging from 0.06 on 7 June to 0.19 on 30 May), close to the value given by Yokouchi et al. (2005). 15 June was the final day of measurements, on which the largest concentrations of several species were measured. The correlation plot for this date is unusual, seeming to consist of two separate populations of points.

Figure 5 plots $\mathrm{CH}_{2} \mathrm{Br}_{2} / \mathrm{CH}_{3} \mathrm{I}$ versus $\mathrm{CH}_{3} \mathrm{I}$. Like the bromocarbons just considered, $\mathrm{CH}_{3} \mathrm{I}$ is expected to have a marine source, but different from the bromocarbons. We see three different periods. From 30 May to approximately 5 June, and from 10-15 June, there is a good correlation with slope of about -0.6 . In contrast between 6 and 8 June 2007, which includes the periods with higher anthropogenic concentrations (see Fig. 3), the correlation is poor and $\mathrm{CH}_{3} \mathrm{I}$ concentrations are low at $\sim 1$ ppt. It seems likely that there has been little recent emission of $\mathrm{CH}_{3} \mathrm{I}$ into these air masses.
Bearing in mind the caveats concerning $\mathrm{CHBr}_{2} \mathrm{Cl}$ and $\mathrm{CH}_{2} \mathrm{Br}_{2}$ (discussed in Sect. 2.2), in Fig. 6 we plot $\mathrm{CHBr}_{3} / \mathrm{CH}_{2} \mathrm{Br}_{2}$ versus $\mathrm{CHBr} 2 \mathrm{Cl} / \mathrm{CH}_{2} \mathrm{Br}_{2}$. The data fit as expected into a region between the 1:1 dilution line and the chemical loss line (see discussion in Sect. 1). They are rather closer to the dilution line, suggesting that the observations might be close (in time) to the source region.

Following Yokouchi et al. (2005) we want to identify a point, at the top right hand of the figure, with maximum ratios of $\mathrm{CHBr}_{3}: \mathrm{CH}_{2} \mathrm{Br}_{2}$ and $\mathrm{CHBr}_{2} \mathrm{Cl}: \mathrm{CH}_{2} \mathrm{Br}_{2}$. The composition of the sampled air mass depends on its history, particularly its exposure to different sources and how these sources vary in time. There are thus various reasons why the maximum values vary from day to day. These variations in the emission ratios over time or space will both introduce scatter to the relationship in Fig. 6, as will experimental uncertainty. Thus, rather than using the absolute maxima we take the values based on 95th and 99th percentiles as representative maximum values. Bearing this in mind, Fig. 6 indicates an emission ratio for $\mathrm{CHBr}_{3} / \mathrm{CH}_{2} \mathrm{Br}_{2}$ of about 9 (13 for 99\%) and a value of around 0.46 (0.53 for 99\%) for $\mathrm{CHBr} 2 \mathrm{Cl} / \mathrm{CH}_{2} \mathrm{Br}_{2}$. The former is similar to that derived by Yokouchi et al. (2005), and is somewhat sensitive to the choice of the maximum ratio. The values for the $\mathrm{CHBr}_{2} \mathrm{Cl} / \mathrm{CH}_{2} \mathrm{Br}_{2}$ ratio show a weaker dependence on the choice of maximum ratio. They span the Yokouchi et al. (2005) value and, given the difficulty of our $\mathrm{CHBr}_{2} \mathrm{Cl}$ measurement, are generally in good agreement. Note that if we take a different value for $\mathrm{CHBr}_{2} \mathrm{Cl}$ in the calibration sample (see Sect. 2.2) the shape of the plot remains the same but 

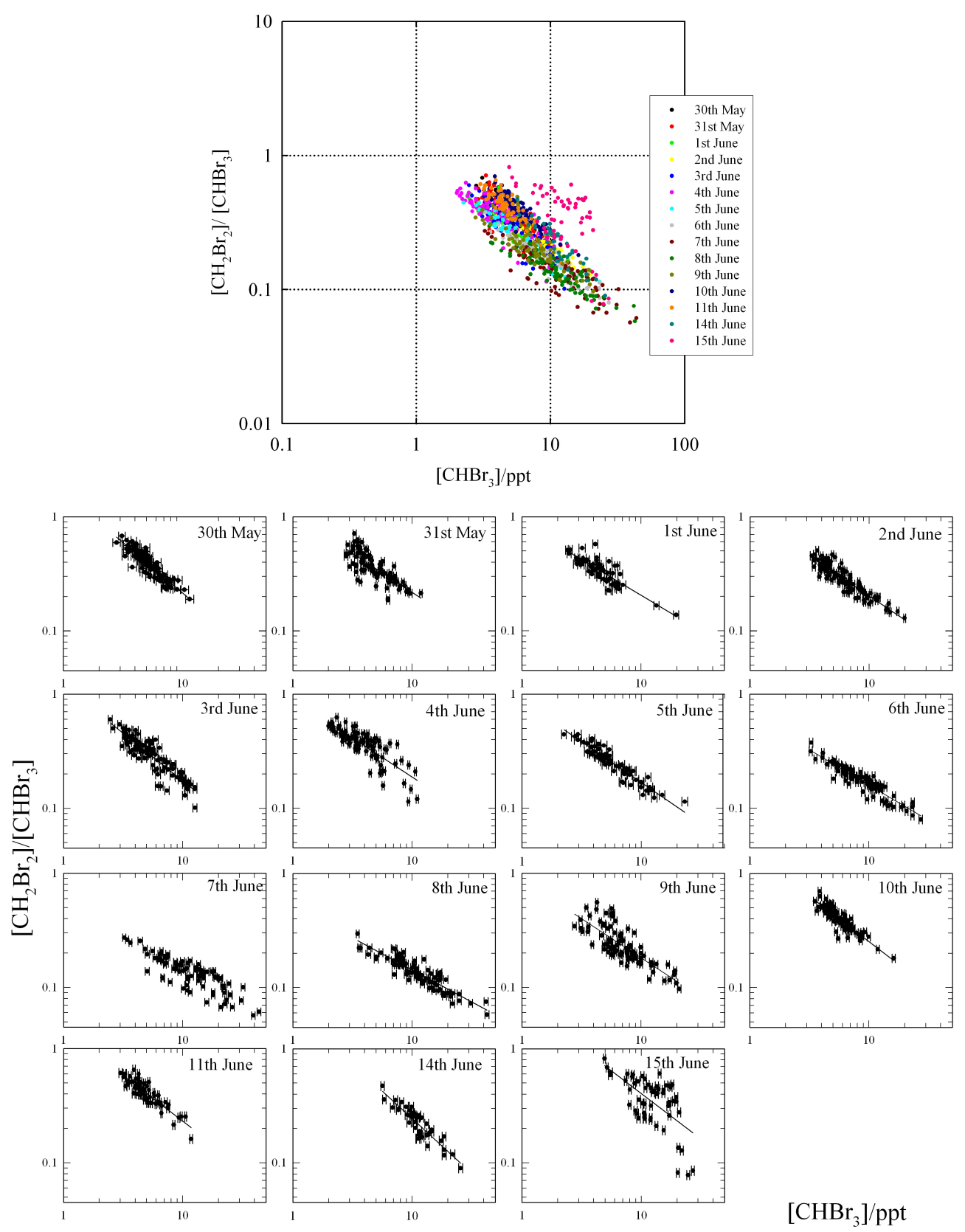

Fig. 4. $\mathrm{CH}_{2} \mathrm{Br}_{2} / \mathrm{CHBr}_{3}$ plotted against $\mathrm{CHBr}_{3}$ for (a) all dates, coloured by day and (b) individual days. Plots are shown on a log-log scale.

is simply shifted horizontally; only the $\mathrm{CHBr} 2 \mathrm{Cl} / \mathrm{CH}_{2} \mathrm{Br}_{2}$ ratio changes. A possible implication of these emission ratios for global fluxes is discussed in Sect. 5 .

\subsubsection{Comparison of measured and modelled bromocarbon concentrations}

Next we use the p-TOMCAT model to ask whether the observed halocarbon measurements, presented above, are consistent with current emission estimates and, if not, what emission distribution is required?
Figure 7 shows modelled halocarbon concentrations at Cape Verde in early June 2007. In MON (not shown) the model significantly underestimates the observed concentrations, with, for example, $\mathrm{CHBr}_{3}$ mixing ratios always less than 1 ppt. The MON emissions taken from Warwick et al. (2006) only include high coastal fluxes between $10^{\circ} \mathrm{N}$ to $10^{\circ} \mathrm{S}$ for $\mathrm{CHBr}_{3}$, and no coastal fluxes for $\mathrm{CH}_{2} \mathrm{Br}_{2}$. Model halocarbon emissions in the region surrounding Cape Verde are therefore low values representative of the open ocean (e.g. $17 \mathrm{nmol} \mathrm{m}^{-2}$ day $^{-1}$ ). They do not include potential emission "hot spots" such as the Mauritanian upwelling, 


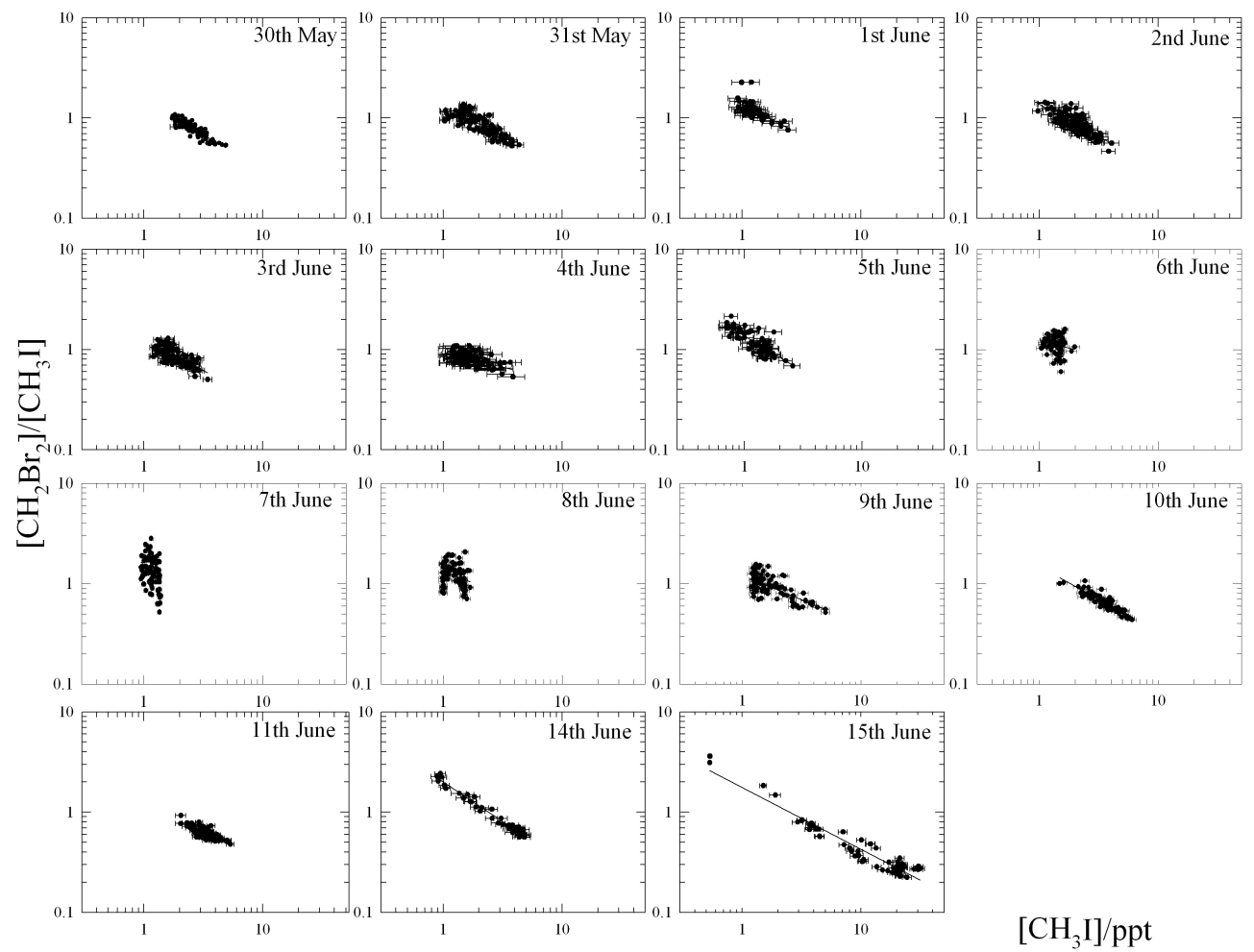

Fig. 5. $\mathrm{CH}_{2} \mathrm{Br}_{2} / \mathrm{CH}_{3} \mathrm{I}$ plotted against $\mathrm{CH}_{3} \mathrm{I}$ for individual days. Plots are shown on a log-log scale.

where observed fluxes of $\mathrm{CHBr}_{3}$ are more than twice the values in MON at around 30-40 $\mathrm{nmol} \mathrm{m}^{-2} \mathrm{day}^{-1}$ (Quack et al., 2007a; Carpenter et al., 2007). However, an extra experiment performed using a $\mathrm{CHBr}_{3}$ flux of $40 \mathrm{nmol} \mathrm{m}^{-2}$ day $^{-1}$ over the upwelling region $\left(16-20^{\circ} \mathrm{W}, 14-20^{\circ} \mathrm{N}\right)$ still does not reproduce the measured high concentrations at Cape Verde. So, in an attempt to find the regional emission flux required to reproduce the observations, we have rather arbitrarily scaled up the $24 \mathrm{~h}$ mean emissions of $\mathrm{CHBr}_{3}$ and $\mathrm{CH}_{2} \mathrm{Br}_{2}$ by factors 10 and 2.5 over a region from $10-20^{\circ} \mathrm{N}$ and $20-30^{\circ} \mathrm{W}$, covering Cape Verde. Model results from this run $(\mathrm{HiBr})$ are shown in Fig. 7. The increased regional emissions correspond to a $\mathrm{CHBr}_{3}$ ocean-atmosphere flux of $170 \mathrm{nmol} \mathrm{m}^{-2}$ day $^{-1}$ (or $14 \mathrm{Gg} \mathrm{Bryr}^{-1}$ ), which is within the (very wide) range of fluxes calculated from near-shore coastal sites in Butler et al. (2007), but significantly higher than fluxes recorded for the larger scale Mauritanian upwelling region (Quack et al., 2007a; Carpenter et al., 2009). For $\mathrm{CH}_{3} \mathrm{I}$ we assumed an ocean-atmosphere flux of $123 \mathrm{nmol} \mathrm{m}^{-2} \mathrm{day}^{-1}$. With these increases in emissions the modelled concentrations of $\mathrm{CH}_{2} \mathrm{Br}_{2}$ and $\mathrm{CH}_{3} \mathrm{I}$ are similar in magnitude to the observations and some of the structure is reproduced (see Fig. 7). If our measured bromocarbon concentrations arise from regional fluxes from the oceanic and coastal waters off West Africa, then our model calculations indicate that these fluxes must be much higher than suggested by local shipboard measurements. However, even then, modelled peak
$\mathrm{CHBr}_{3}$ is about half that observed. Despite the lower concentrations compared with the observations, it is interesting that the model reproduces an increase in bromoform around 7-10 June. Winds in the surface model layer (and in the atmosphere) were very low at this time and the increase reflects a stable, confined boundary layer.

It is clear from Fig. 1 that the trajectories for this period spent several days below about $1 \mathrm{~km}$ and, as discussed in Sect. 4.1, they passed close to regions with high potential for biological productivity, as indicated by observations from the SeaWifs satellite. This could perhaps at least partially explain the high concentrations. To see whether coastal emissions also might have played a role, a second extra modelling experiment was performed using a $\mathrm{CHBr}_{3}$ flux of $40 \mathrm{nmol} \mathrm{m}^{-2}$ day $^{-1}$ over the West African coastline only (between $14-20^{\circ} \mathrm{N}$ ). Results from this calculation show that a coastal source has almost no effect on the modelled halocarbon concentrations at Cape Verde during the first two weeks of June. Indeed, the trajectory analysis confirms that the air masses reaching the archipelago have spent little time close to these coastlines.

We could have increased the emissions of bromoform still further in an attempt to reproduce the observations around 7 and 8 June. However, the observations could also be consistent with a more localised source of bromoform closer to Cape Verde. Notice that the observations have a diurnal variation, especially around 7-10 June, with peak concentrations 


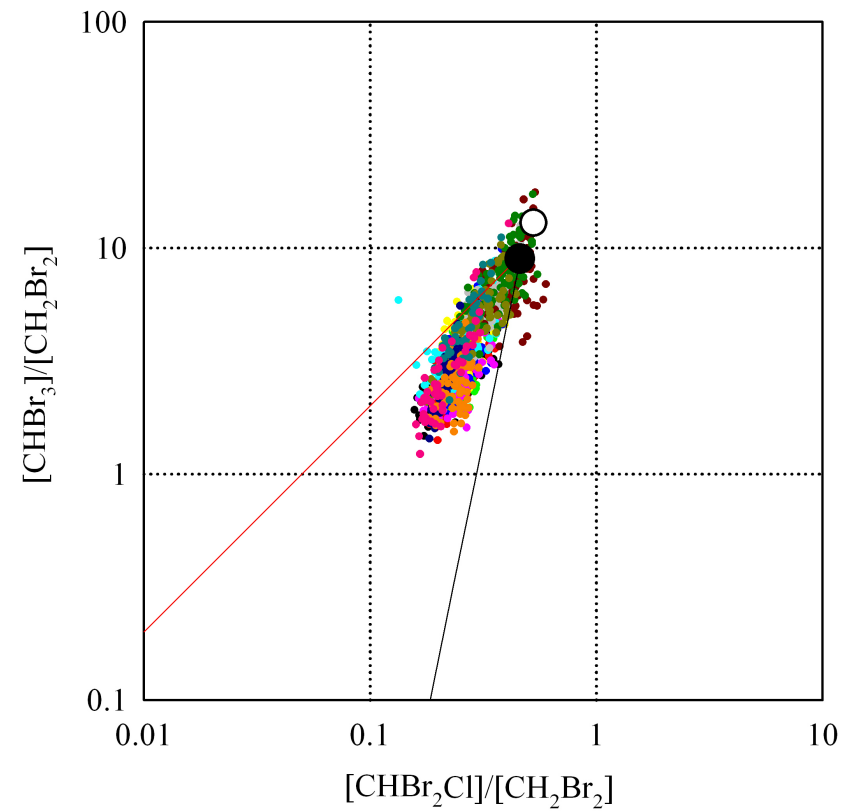

Fig. 6. $\mathrm{Log}-\log$ plots of $\mathrm{CHBr}_{3} / \mathrm{CH}_{2} \mathrm{Br}_{2}$ versus $\mathrm{CHBr} 2 \mathrm{Cl} / \mathrm{CH}_{2} \mathrm{Br}_{2}$, following Yokouchi et al. (2005). All of the data are shown in this plot. The solid red line is the 1:1 dilution line. The solid black line is the chemical decay line, estimated from the lifetime of the 3 species. In this case, we have followed the example of Yokouchi et al. (2005) and used lifetimes of 26 days, 69 days and 120 days respectively for $\mathrm{CHBr}_{3}, \mathrm{CHBr}_{2} \mathrm{Cl}$ and $\mathrm{CH}_{2} \mathrm{Br}_{2}$. Thus the chemical decay line has a slope of 4.89 . The large black point near the top of the data set is the estimated emission ratio of the compounds (where ratios are at a maximum), based on 95 th percentiles. Similarly the open circle is based on 99th percentiles.

in the early afternoon (see Figs. 2 and 8, below). Bromoform has a lifetime in the tropics of 2 weeks or so, and it is difficult to imagine that the diurnal variation is photochemically driven. One possibility is that local marine sources have a diurnal variation (Quack and Wallace, 2003) and that the bromoform is being sampled soon enough after emission for neither mixing nor atmospheric chemistry to remove the diurnal structure. Figure 7, which shows the $\mathrm{HiBr}$ calculation in which the regional emissions were increased during the daytime, does show some evidence of diurnal behaviour on 10 and 11 June, while a run with the same emissions, spread across $24 \mathrm{~h}$, does not. We did notice seaweeds close to the site, and these may have constituted a local source, but we did not make systematic observations, which would be required. Furthermore, there is no relationship to tidal variations evident in our measurements. An alternative explanation is that the diurnal variation is related to transport and changes in the local winds, rather than diurnal variations in the biogenic emissions. Local wind and $\mathrm{CO}$ data from the observatory (L. Carpenter, personal communication, 2009) exhibits diurnal variability, with wind speeds peaking in the afternoon, and $[\mathrm{CO}]$ reducing after midday coincident with increases in

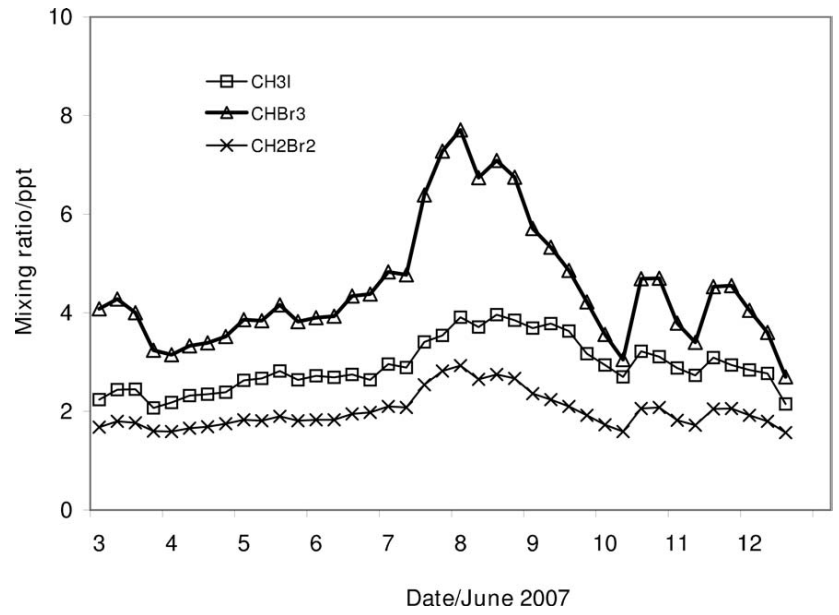

Fig. 7. Simulated $\mathrm{CH}_{3} \mathrm{I}, \mathrm{CH}_{2} \mathrm{Br}_{2}$ and $\mathrm{CHBr}_{3}$ over Cape Verde after scaling up the emission flux for each species within the region 10 $20^{\circ} \mathrm{N}, 20-30^{\circ} \mathrm{W}$ (covering the Cape Verde islands).

[CHBr 3 ]. The cause of the diurnal variation in bromoform is not clear; diurnally varying emissions may play a role but more evidence would be required to make a convincing case.

\subsection{Implications of high bromocarbons for radical species, oxidizing capacity and ozone}

We now use p-TOMCAT to address two further questions:

- Read et al. (2008) have shown that throughout the year there are high concentrations of $\mathrm{BrO}$ and $\mathrm{IO}$ at Cape Verde, which play an important role in controlling ozone concentrations. Are the bromine sources, based on our observed halocarbons and modelled sea salt emissions, consistent with observed $\mathrm{BrO}$ at Cape Verde of around 2-3 ppt (Read et al., 2008)?

- Figure 8 plots the two-hour running mean of the measured bromoform alongside the surface ozone measurements from the observatory. During the period with elevated $\mathrm{CHBr}_{3}$, the ozone concentration declines by about $10 \mathrm{ppb}$ (and shows a clearly defined diurnal variation). Can we model these observed changes in ozone at Cape Verde during early June 2007?

Figure 9 shows modelled $\mathrm{BrO}$ at Cape Verde for the period in early June 2007, for the model integrations outlined in Table 1. None of the model runs discussed in Sect. 4.2 are able to reproduce the average $\mathrm{BrO}(2-3 \mathrm{ppt})$ reported by Read et al. (2008). For example, the run with elevated bromocarbon emissions close to Cape Verde ( $\mathrm{HiBr}$ ) produces only a low $\mathrm{BrO}$ level of $\sim 0.3 \mathrm{ppt}$ at noon. The bromocarbons included in the model are the major known natural organic sources of bromine. With lifetimes ranging from 


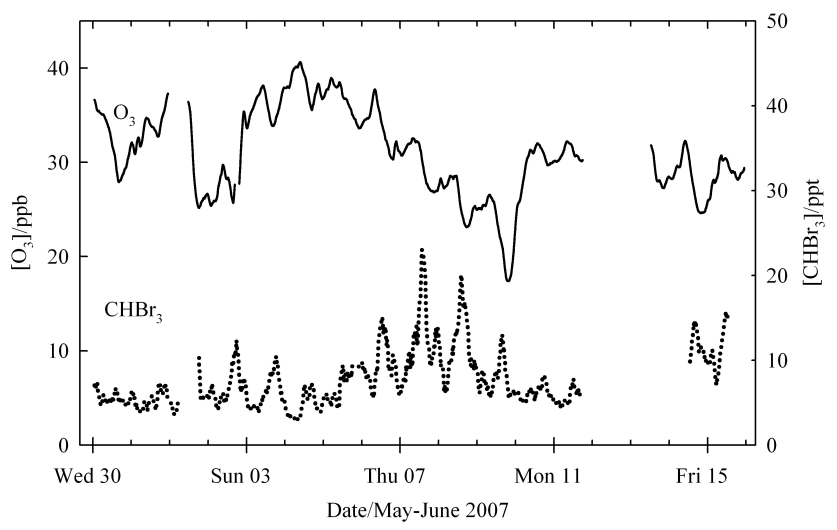

Fig. 8. Two-hourly running mean of surface ozone (data courtesy of University of York) and $\mathrm{CHBr}_{3}$.

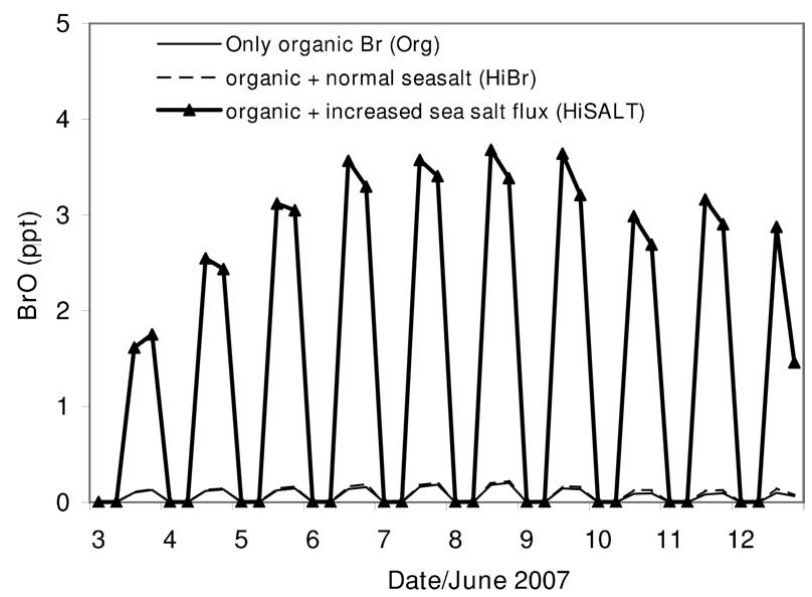

Fig. 9. Simulated $\mathrm{BrO}$ over Cape Verde, with different bromine sources. The thin solid line represents the model run with bromocarbons only (Org); the dashed line represents the model run with an organic bromine source plus normal sea salt production from the open ocean, calculated by the Monahan et al. (1986) formula (HiBr). The solid line with triangles represents the run with an organic bromine source plus an elevated inorganic source over the region $10-20^{\circ} \mathrm{N}, 20-30^{\circ} \mathrm{W}$ (HiSALT).

weeks to months, their high local concentrations do not lead to simultaneously high local concentrations of the radical species. A very important known source of reactive bromine to the lowermost troposphere is sea salt (Sander et al., 2003; Yang et al., 2005). Wind stress at the ocean surface lifts droplets which evaporate and form sea salt aerosol particles, which can subsequently liberate bromine into the atmosphere. The flux of particles is a strong function of surface wind speed. The model resolution of approximately $3^{\circ} \times 3^{\circ}$ will average gustiness and, with typical model wind speeds close to Cape Verde of about $6 \mathrm{~ms}^{-1}$, sea salt aerosols from the open ocean make almost no contribution to modelled $\mathrm{BrO}$ (Fig. 9).

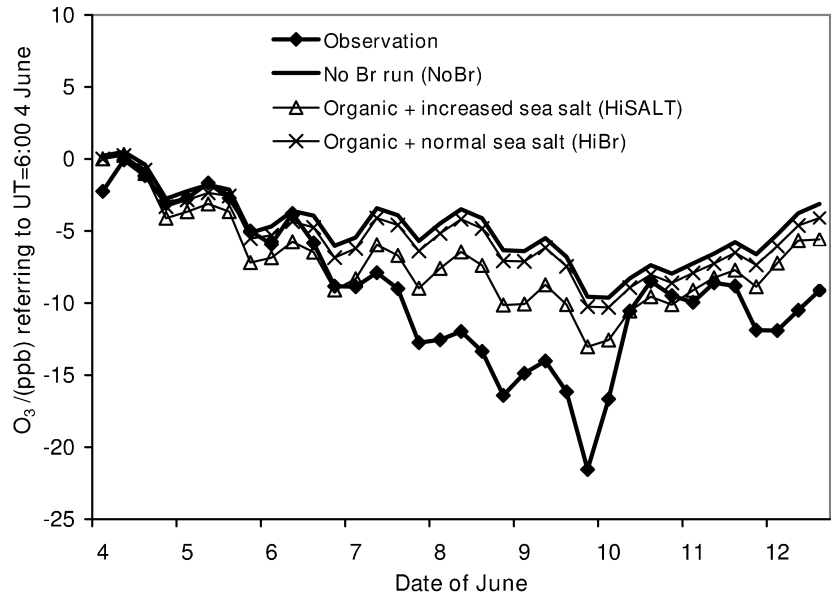

Fig. 10. Observed and modelled ozone differences referring to values at UT=06:00 on 4 June. Modelled runs are $\mathrm{NoBr}, \mathrm{HiBr}$ and HiSALT.

We have arbitrarily increased the modelled sea salt emission to reproduce the observed $\sim 3 \mathrm{ppt}$ of $\mathrm{BrO}$. In this case a bromine flux of $0.4 \times 10^{-12} \mathrm{~kg} \mathrm{~m}^{-2} \mathrm{~s}^{-1}$, in the form of $\mathrm{Br}_{2}$, must be used. Because of our focus on Cape Verde, and to avoid altering the oxidising capacity of the global atmosphere, emissions were only increased between $10-20^{\circ} \mathrm{N}, 20-30^{\circ} \mathrm{W}$. To produce this high $\mathrm{Br}$ flux in our sea salt production calculation (based on the Monahan et al., 1986 flux parameterisation and with a size-dependent bromine depletion factor, Yang et al., 2008) would have required a mean wind speed of $13 \mathrm{~ms}^{-1}$. The imposed flux is more than 10 times higher than the averaged flux $\left(0.03 \times 10^{-12} \mathrm{~kg} \mathrm{~m}^{-2} \mathrm{~s}^{-1}\right)$ calculated under a mean wind speed of $6 \mathrm{~ms}^{-1}$ for this period. Although the high wind speed of $13 \mathrm{~ms}^{-1}$ clearly exceeds the average wind speed in the tropics and suggests that sea salt from the open ocean is not the major bromine source maintaining such high $\mathrm{BrO}$ concentrations, there are other possibilities. For example, the air-sea flux treatments for aerosol we have used could be inappropriate, or the observationally-based sea salt bromine depletion factor currently used (Yang et al., 2008) could be too low in this region. The model resolution could be too coarse to capture average emissions given the non-linear dependence of emissions on wind speed. Alternatively, note that the high $\mathrm{BrO}$ is measured at a coastal site, where surf could lead to a significant sea salt production rate even under low wind speeds (de Leeuw et al., 2000). The surf zone could possibly be a potentially large bromine source, although this may be limited to only a relatively narrow region along coasts. Measurements of $\mathrm{BrO}$ in the marine boundary layer away from coastal sites would be required to test this possibility. However, if production of $\mathrm{BrO}$ is confined to the surf zone, it would be difficult to explain the ozone losses reported by Read et al. (2008). 
Figure 10 shows the observed (6h mean) and simulated ozone during the period 4-12 June (all results are differences, relative to the values at UT=06:00 on 4 June). Throughout the period from 4 to 10 June, the observed ozone declines, with a maximum reduction of more than $20 \mathrm{ppb}$ around 10 June, which corresponds to the period with the very stable boundary layer. The model run without bromine chemistry also shows a similar decline, but with only half the depth of observed peak ozone reduction ( $\sim 10 \mathrm{ppb})$. The $\mathrm{HiBr}$ run is rather similar to the run without bromine chemistry and again fails to reproduce the magnitude of the observed changes. The model calculation with the increased inorganic bromine source (HiSALT), which leads to BrO levels of around $3 \mathrm{ppt}$, is closer to the observations and ozone loss is increased up to $4 \mathrm{ppb}$ during this period. The magnitude of the short-fall is largest when the boundary layer is most stable and might be related, for example, to reduced vertical mixing (corresponding to higher $\mathrm{BrO}$ concentrations, see Fig. 9, and less entrainment of ozone-rich air from aloft). However, even with elevated $\mathrm{BrO}$ of around $3 \mathrm{ppt}$, this still leaves an ozone decline of more than $5 \mathrm{ppb}$ to be explained by other processes. Given the sporadic high methyl iodide concentrations we have measured, and the high IO reported by Read et al. (2008), iodine (and iodine-bromine) chemistry could be a possible explanation. This would also be consistent with recent studies in the polar regions (Saiz-Lopez et al., 2007). Note that our 3-D modelled bromine-induced ozone loss is much higher than from the box model calculation by Read et al. (2008). We believe our modelled $\mathrm{Br}$ atom concentration must be higher than in their calculation. One reason could be that our 3-D model has a much larger $\mathrm{Br}_{2}$ flux than the box model; $\mathrm{p}$-TOMCAT contains very effective wet removal processes (mainly through $\mathrm{HBr}$, Yang et al., 2005), while the box model used by Read et al. (2008) has only dry deposition as a sink for the inorganic bromine species. Other dynamical processes, such as venting and transport, may also affect the boundary layer bromine budget in our 3-D model. Thus although similar $\mathrm{BrO}$ levels are predicted by the two models, p-TOMCAT, with its stronger $\mathrm{Br}_{2}$ emissions, would calculate greater ozone loss.

\section{Summary and discussion}

The $\mu$-Dirac gas chromatograph was deployed for several weeks at the Cape Verde observatory. It measured concentrations of a range of anthropogenic and biogenic halocarbons and demonstrated its potential for long-term autonomous measurement. Bromoform $\left(\mathrm{CHBr}_{3}\right)$ exhibits the most variability of all the halocarbons observed, ranging from a background concentration of about $3-5$ ppt to a maximum of $>40$ ppt during the course of the measurement period. This range of mixing ratios, and variability, is consistent with previous tropical measurements, particularly those in coastal regions (e.g. Quack et al., 2004; Yokouchi et al., 2005; Carpenter et al., 2007); open ocean measurements over the tropical North Atlantic Ocean suggest a lower background than our measurements. $\mathrm{CH}_{2} \mathrm{Br}_{2}$ correlates well with bromoform, with a slope similar to that reported by Yokouchi et al. (2005), suggesting a common regional source. Methyl iodide does not correlate with these bromocarbons. Base levels of around 1-2 ppt were measured but with some periods of much higher mixing ratios. The indications are that the sources of the biogenic bromocarbons are different to those of $\mathrm{CH}_{3} \mathrm{I}$, as expected. Measurements of $\mathrm{C}_{2} \mathrm{Cl}_{4}$ and $\mathrm{CHCl}_{3}$ correlate well with $\mathrm{CO}$ and are good indicators of anthropogenic emissions, complementing the biogenic species mentioned above.

The highest concentrations of bromoform were measured in early June when air parcels had crossed the open ocean, including the Mauritanian upwelling, off the west coast of Africa. While the p-TOMCAT model could capture the period of highest concentrations around 7-9 June, quantitative agreement required emissions which were much larger than have been measured over the open ocean. Neither our trajectory nor our chemical transport model calculations indicated a role for a West African emissions source during this short period of measurements. A possible explanation for our high measurements could be local emissions. It is worth emphasising that low resolution models will have difficulty in reproducing observed concentrations if the spatial scale of the emissions is less than the grid size; the problem will be ill-posed.

A combination of measurements and modelling is necessary to improve our understanding of global halocarbon emissions. In this study, the method following Yokouchi et al. (2005) and McKeen and Liu (1993) is used to derive emission flux ratios for $\mathrm{CHBr}_{3}, \mathrm{CH}_{2} \mathrm{Br}_{2}$ and $\mathrm{CHBr}_{2} \mathrm{Cl}$ in the region surrounding Cape Verde. The calculated ratios in this study (9 for $\mathrm{CHBr}_{3}: \mathrm{CH}_{2} \mathrm{Br}_{2}$ and 0.46 for $\mathrm{CHBr}_{2} \mathrm{Cl}_{2} \mathrm{CH}_{2} \mathrm{Br}_{2}$ based on 95th percentiles; 13 for $\mathrm{CHBr}_{3}: \mathrm{CH}_{2} \mathrm{Br}_{2}$ and 0.53 for $\mathrm{CHBr}_{2} \mathrm{Cl}: \mathrm{CH}_{2} \mathrm{Br}_{2}$ based on 99th percentiles) are similar to those obtained in the tropics by Yokouchi et al. (2005), but are significantly higher than emission ratios calculated in global studies. For example, the WMO (2003) sinkbased bromocarbon emission estimates give molar ratios of 2.3 for $\mathrm{CHBr}_{3}: \mathrm{CH}_{2} \mathrm{Br}_{2}$ and 0.2 for $\mathrm{CHBr}_{2} \mathrm{Cl}: \mathrm{CH}_{2} \mathrm{Br}_{2}$. The Warwick et al. (2006) model study, using a predominantly tropical emission dataset and higher emissions than WMO (2003), gives similar low molar emission ratios of 3.6 for $\mathrm{CHBr}_{3}: \mathrm{CH}_{2} \mathrm{Br}_{2}$ and 0.2 for $\mathrm{CHBr}_{2} \mathrm{Cl}: \mathrm{CH}_{2} \mathrm{Br}_{2}$. A bottom-up study by Butler et al. (2007), which estimated global emissions of $\mathrm{CHBr}_{3}$ and $\mathrm{CH}_{2} \mathrm{Br}_{2}$, based on ship-based observations of surface water and atmospheric concentrations, gives a global emission ratio of 1.9 for $\mathrm{CHBr}_{3}: \mathrm{CH}_{2} \mathrm{Br}_{2}$. The large difference between the regional estimates of emission ratios and those obtained from global studies suggests that while regional emission ratios may be valid for near-shore regions, there remains some question over whether (and how) they can be extrapolated on a global scale. Conversely, the strong local emissions may not be included in the global estimates. 
With these caveats in mind, we can nevertheless extrapolate our local emission ratios to give an estimate of global emissions. If we assume a global emission (taken from WMO, 2003) of $61 \mathrm{Gg} \mathrm{Bryr}^{-1}$ for $\mathrm{CH}_{2} \mathrm{Br}_{2}$, this leads to global emissions of $823 \mathrm{Gg} \mathrm{Br} \mathrm{yr}^{-1}$ for $\mathrm{CHBr}_{3}$ (1190 $\mathrm{Gg} \mathrm{Bryr}^{-1}$ for 99 th percentile) and $28 \mathrm{Gg} \mathrm{Bryr}^{-1}$ for $\mathrm{CHBr}_{2} \mathrm{Cl}\left(32 \mathrm{Gg} \mathrm{Bryr}^{-1}\right.$ for $\left.99 \%\right)$. Using the higher $\mathrm{CH}_{2} \mathrm{Br}_{2}$ global emission of $104 \mathrm{Gg} \mathrm{Br} \mathrm{yr}^{-1}$ from Warwick et al. (2006), this corresponds to global emissions of $1404 \mathrm{Gg} \mathrm{Br} \mathrm{yr}^{-1}$ for $\mathrm{CHBr}_{3}\left(2028 \mathrm{Gg} \mathrm{Br} \mathrm{yr}^{-1}\right.$ for $99 \%$ ) and $48 \mathrm{Gg} \mathrm{Br} \mathrm{yr}^{-1}$ for $\mathrm{CH}_{2} \mathrm{BrCl}\left(55 \mathrm{Gg} \mathrm{Br} \mathrm{yr}^{-1}\right.$ for $\left.99 \%\right)$. In either case, these are much higher than estimated in WMO (2003).

The global estimates of $\mathrm{CHBr}_{3}$ and $\mathrm{CHBr}_{2} \mathrm{Cl}$ emissions derived from the correlation plots depend on a number of factors. Firstly, local (coastal) measurements are being extrapolated globally. Secondly, the choice of maximum ratio, especially in the case of $\mathrm{CHBr}_{3} / \mathrm{CH}_{2} \mathrm{Br}_{2}$, introduces considerable uncertainty. There is also uncertainty in the value chosen for $\mathrm{CH}_{2} \mathrm{Br}_{2}$ emissions. Although $\mathrm{CH}_{2} \mathrm{Br}_{2}$ emissions are believed to be better constrained than other bromocarbons due to its longer lifetime, there is still significant uncertainty in global emission estimates. The WMO (2003) sink-based estimate $\left(66 \mathrm{Gg} \mathrm{CH}_{2} \mathrm{Br}_{2} \mathrm{yr}^{-1}\right.$ ) is significantly smaller than the emissions required by the 3-D model study by Warwick et al. (2006) to reproduce observations based on a predominantly tropical emission dataset $\left(113 \mathrm{Gg} \mathrm{CH}_{2} \mathrm{Br}_{2} \mathrm{yr}^{-1}\right)$. This demonstrates that even for $\mathrm{CH}_{2} \mathrm{Br}_{2}$, the geographical distribution of its emissions can have an important impact on the global atmospheric lifetime and thus the global sink-based emission estimate. Evidently there are still important questions about halocarbon emissions. Their resolution calls for a measurement/modelling programme involving both local and global measurements.

Even when the local emissions in the model are increased to allow a reasonable representation of the observed bromocarbons at Cape Verde, the modelled $\mathrm{BrO}$ is well below the observed 2-3 ppt reported by Read et al. (2008). A possible explanation for the observed $\mathrm{BrO}$ could be inorganic emissions, from sea salt. These had to be increased very substantially to match the high $\mathrm{BrO}$, implying unrealistically high regional wind speeds across the ocean surface. Alternatively, it could be that the parameterisation of sea-salt aerosol production over the open ocean is inadequate. We noted the ubiquitous presence of sea salt deposits on buildings, etc. It seems possible that a very local source, associated with the coastal surf zone, could be playing a role. Measurements of $\mathrm{BrO}$ in the free marine boundary layer could help to resolve this question.

Throughout the period of our halocarbon measurements, and especially from 4 to 10 June, the observed ozone declines, with a maximum reduction of about $20 \mathrm{ppb}$ around 10 June, which corresponds to the period with a very stable boundary layer. When high $\mathrm{BrO}$ is modelled by artificially increasing the sea salt source we do reproduce part of the ob- served ozone decline (perhaps by 3-4 ppb, still leaving about $5 \mathrm{ppb}$ ozone decline to be explained by other processes). The magnitude of the short-fall is largest when the boundary layer is most stable and might be related to increased deposition. However, this is a slow process in the marine boundary layer and other chemical explanations seem more likely. For example, if a very local source of the halogens is operating, its effect would be most evident under these stable conditions. Given the sporadic high concentrations of methyl iodide we have measured, and the high IO reported by Read et al. (2008), it seems likely that iodine (and iodine-bromine) chemistry is an important part of the explanation.

Acknowledgements. This work was supported by NERC, NCAS and by the European Commission through the SCOUT-O3 project (505390-GOCE-CF2004). Louise O'Brien thanks NERC for a research studentship. Andrew Robinson acknowledges NERC for their support through small grant project NE/D008085/1. Deployment costs to Cape Verde were provided by the UK NERC SOLAS program (RHaMBLe project, Ally Lewis). We thank James Lee, Katie Read, Alastair Lewis and Lucy Carpenter from the University of York, UK, and Luis Mendes and Paulo Mendes from INMG, Cape Verde, for allowing us to use their $\mathrm{CO}$ and $\mathrm{O}_{3}$ data in this paper. We acknowledge the British Atmospheric Data Centre (BADC) web trajectory service, and also thank Dickon Young and Simon O'Doherty at the University of Bristol for useful correspondence.

Edited by: W. T. Sturges

\section{References}

Barrie, L. A., Bottenheim, J. W., Schnell, R. C., Crutzen, P. J., and Rasmussen, R. A.: Ozone destruction and photochemical reactions at polar sunrise in the lower Arctic atmosphere, Nature, 334, 138-141, 1988.

Bassford, M. R., Nickless, G., Simmonds, P. G., Lewis, A. C., Pilling, M. J., and Evans, M. J.: The concurrent observation of methyl iodide and dimethyl sulphide in marine air: implications for sources of atmospheric methyl iodide, Atmos. Environ., 33, 2373-2383, 1999.

Butler, J. H., King, D. B., Lobert, J. M., Montzka, S. A., YvonLewis, S. A., Hall, B. D., Warwick, N. J., Mondeel, D. J., Aydin, M., and Elkins, J. W.: Oceanic distributions and emissions of short-lived halocarbons, Global Biogeochem. Cy., 21, GB1023, doi:10.1029/2006GB002732, 2007.

Carpenter, L. J. and Liss, P. S.: On temperate sources of bromoform and other reactive bromine gases, J. Geophys. Res., 105(D12), 20539-20547, 2000.

Carpenter, L. J., Liss, P. S., and Penkett, S. A.: Marine organohalogens in the atmosphere over the Atlantic and Southern Oceans, J. Geophys. Res., 108(D9), 4256, doi:10.1029/2002JD002769, 2003.

Carpenter, L. J., Wevill, D. J., O’Doherty, S., Spain, G., and Simmonds, P. G.: Atmospheric bromoform at Mace Head, Ireland: seasonality and evidence for a peatland source, Atmos. Chem. Phys., 5, 2927-2934, 2005,

http://www.atmos-chem-phys.net/5/2927/2005/. 
Carpenter, L., Wevill, D. J., Hopkins, J. R., Dunk, R. M., Jones, C. E., Hornsby, K. E., and McQuaid, J. B.: Bromoform in tropical Atlantic air from $25^{\circ} \mathrm{N}$ to $25^{\circ} \mathrm{S}$, Geophys. Res. Lett., 34, L11810, doi:10.1029/2007/GL029893, 2007.

Carpenter, L. J., Jones, C. E., Dunk, R. M., Hornsby, K. E., and Woeltjen, J.: Air-sea fluxes of biogenic bromine from the tropical and North Atlantic Ocean, Atmos. Chem. Phys., 9, 1805-1816, 2009,

http://www.atmos-chem-phys.net/9/1805/2009/.

Chipperfield, M. P. and Pyle, J. A.: Model sensitivity studies of Arctic ozone depletion, J. Geophys. Res., 103(D19), 28398-28403, 1998.

Chuck, A. L., Turner, S. M., and Liss, P. S.: Oceanic distributions and air-sea fluxes of biogenic halocarbons in the open ocean, J. Geophys. Res., 110, C10022, doi:10.1029/2004JC002741, 2005.

Class, Th. and Ballschmiter, K.: Chemistry of organic traces in air V: Determination of halogenated C1-C2-hydrocarbons in clean marine air and ambient continental air and rain by high resolution gas chromatography using different stationary phases, Fresen. Z. Anal. Chem., 325, 1-7, 1986.

Class, Th., Kohnle, R., and Ballschmiter, K.: Chemistry of organic traces in air VII: Bromo- and bromochloromethanes in air over the Atlantic Ocean, Chemosphere, 15(4), 429-436, 1986.

Class, T. H. and Ballschmiter, K.: Chemistry of organic traces in air: sources and distribution of bromo- and bromochloromethanes in marine air and surfacewater of the Atlantic Ocean, J. Atmos. Chem., 6, 35-46, 1988.

Cook, P. A., Savage, N. H., Turquety, S., Carver, G. D., O’Connor, F. M., Heckel, A., Stewart, D., Whalley, L. K., Parker, A. E., Schlager, H., Singh, H. B., Avery, M. A., Sachse, G. W., Brune, W., Richter, A., Burrows, J. P., Purvis, R., Lewis, A. C., Reeves, C. E., Monks, P. S., Levine, J. G., and Pyle, J. A.: Forest fire plumes over the North Atlantic: p-TOMCAT model simulations with aircraft and satellite measurements from the ITOP/ICARTT campaign, J. Geophys. Res., 112, D10S43, doi:10.1029/2006JD007563, 2007.

de Leeuw, G., Neele, F., Hill, M., Smith, M., and Vignati, E.: Production of sea spray aerosol in the surf zone, J. Geophys. Res., 105(D24), 29397-29409, 2000.

Dorf, M., Butler, J. H., Butz, A., Camy-Peyret, C., Chipperfield, M. P., Kritten, L., Montzka, S. A., Simmes, B., Weidner, F., and Pfeilsticker, K.: Long-term observations of stratospheric bromine reveal slow down in growth, Geophys. Res. Lett., 33, L24803, doi:10.1029/2006GL027714, 2006.

Dressler, M.: Selective gas chromatographic detectors, J. Chromatog. Libr., 36, 217-271, 1986.

Ekdahl, A., Pedersén, M., and Abrahamsson, K.: A study of the diurnal variation of biogenic volatile halocarbons, Mar. Chem., 63, 1-8, 1998.

Gostlow, B., Robinson, A. D., Harris, N. R. P., O'Brien, L. M., Oram, D. E., Mills, G. P., Newton, H. M., and Pyle, J. A.: $\mu$ Dirac: an autonomous instrument for halocarbon measurements, Atmos. Meas. Tech. Discuss., 2, 2123-2159, 2009, http://www.atmos-meas-tech-discuss.net/2/2123/2009/.

Grose, M. R., Cainey, J. M., McMinn, A., and Gibson, J. A. E.: Coastal marine methyl iodide source and links to new particle formation at Cape Grim during February 2006, Environ. Chem., 4, 172-177, 2007.

Kritz, M. A. and Rancher, J.: Circulation of $\mathrm{Na}, \mathrm{Cl}$ and $\mathrm{Br}$ in the tropical marine atmosphere, J. Geophys. Res, 85(C3), 16331639, 1980.

Kurylo, M. J., Rodriguez, J. M. (Lead authors), Andreae, M. O., Atlas, E. L., Blake, D. R., Butler, J. H., Lal, S., Lary, D. J., Midgely, P. M., Montzka, S. A., Novelli, P. C., Reeves, C. E., Simmonds, P. G., Steele, L. P., Sturges, W. T., Weiss, R. F., and Yokouchi, Y.: Short-lived ozone related compounds, Chapter 2 in: Scientific Assessment of Ozone Depletion: 1998, Global Ozone Research and Monitoring Project, Report No. 44, World Meteorological Organization, Geneva, Switzerland, 1999.

Law, K., Plantevin, P.-H., Thouret, V., Marenco, A., Asman, W., Lawrence, M., Crutzen, P., Muller, J. F., Hauglustaine, D., and Kanakidou, M.: Comparison between global chemistry transport model results and measurement of Ozone and Water Vapour by Airbus-In-Service Aircraft (MOZAIC) data, J. Geophys. Res., 105(D1), 1503-1525, 2000.

Law, K. S., Sturges, W. T., Blake, D. R., Blake, N. J., Burkholder, J. B., Butler, J. H., Cox, R. A., Haynes, P. H., Ko, M. K. W., Kreher, K., Mari, C., Pfeilsticker, K., Plane, J. M. C., Salawitch, R. J., Schiller, C., Sinnhuber, B.-M., von Glasow, R., Warwick, N. J., Wuebbles, D. J., and Yvon-Lewis, S. A.: Halogenated very short-lived substances, Chapter 2 in: Scientific Assessment of Ozone Depletion: 2006, Global Ozone Research and Monitoring Project, Rep. No. 50, World Meteorological Organization, Geneva, Switzerland, 2007.

Lovelock, J. E.: Ionization methods for the analysis of gases and vapours, Anal. Chem., 33(2), 162-178, 1961.

McKeen, S. A. and Liu, S. C.: Hydrocarbon ratios and photochemical history of air masses, Geophys. Res. Lett., 20, 2363-2366, 1993.

Monahan, E. C., Spiel, D. E., and Davidson, K. L.: A model of marine aerosol generation via whitecaps and wave disruption, in: Oceanic Whitecaps, edited by: Monahan, E. C. and Mac Niocail, G., D. Reidel, Norwell, MA, 167-174, 1986.

Moore, R. M. and Tokarczyk, R.: Volatile biogenic halocarbons in the northwest Atlantic, Global Biogeochem. Cy., 7, 195-210, 1993.

Moore, R. M., Webb, M., Tokarczyk, R., and Wever, R.: Bromoperoxidase and iodoperoxidase enzymes and production of halogenated methanes in marine diatom cultures, J. Geophys. Res., 101, 20899-20908, 1996.

Norton, T. A. and Mathieson, A. C.: The biology of unattached seaweeds, in: Progress in Phycological Research, edited by: Round, F. and Chapman, D., Elsevier Sci. Publ., Amsterdam, 2, 333 386, 1983.

Penkett, S. A., Jones, B. M. R., and Rycroft, M. J.: An interhemispheric comparison of the concentrations of bromine compounds in the atmosphere, Nature, 318, 550-553, 1985.

Pfeilsticker, K., Sturges, W. T., Bösch, H., Camy-Peyret, C., Chipperfield, M. P., Engel, A., Fitzenberger, R., Müller, M., Payan, S., and Sinnhuber, B.-M.: Lower stratospheric organic and inorganic bromine budget for the arctic winter 1998/99, Geophys. Res. Lett., 27(20), 3305-3308, 2000.

Quack, B. and Wallace, D. W. R.: Air-sea flux of bromoform: Controls, rates and implications, Global. Biogeochem. Cy., 17(1), 1023, doi:10.1029/2002GB001890, 2003.

Quack, B., Atlas, E., Petrick, G., Schauffler, S., and Wallace, D.: Oceanic bromoform sources for the tropical atmosphere, Geophys. Res. Lett., 31, L23505, doi:10.1029/2004GL020597, 2004. 
Quack, B., Peeken, I., Petrick, G., and Nachtigall, K.: Oceanic distribution and sources of bromoform and dibromomethane in the Mauritanian upwelling, J. Geophys. Res., 112, C100006, doi:10.1029/2006JC003803, 2007a.

Quack, B., Atlas, E., Petrick, G., and Wallace, D. W. R.: Bromoform and dibromomethane above the Mauritanian upwelling: Atmospheric distributions and oceanic emissions, J. Geophys. Res.Atmos., 112, D09312, doi:10.1029/2006JD007614, 2007b.

Read, K. A., Mahajan, A. S., Carpenter, L. J., Evans, M. J., Faria, B. V. E., Heard, D. E., Hopkins, J. R., Lee, J. D., Moller, S. J., Lewis, A. C., Mendes, L., McQuaid, J. B., Oetjen, H., SaizLopez, A., Pilling, M. J., and Plane, J. M. C.: Extensive halogenmediated ozone destruction over the tropical Atlantic Ocean, Nature, 453, 1232-1235, doi:10.1038/nature07035, 2008.

Robinson, A. D., McIntyre, J., Harris, N. R. P., Pyle, J. A., Simmonds, P. G., and Danis, F.: A lightweight balloon-borne gas chromatograph for in-situ measurements of atmospheric halocarbons, Rev. Sci. Instrum., 71, 4553-4560, 2000.

Robinson, A. D., Millard, G. A., Danis, F., Guirlet, M., Harris, N. R. P., Lee, A. M., McIntyre, J. D., Pyle, J. A., Arvelius, J., Dagnesjo, S., Kirkwood, S., Nilsson, H., Toohey, D. W., Deshler, T., Goutail, F., Pommereau, J.-P., Elkins, J. W., Moore, F., Ray, E., Schmidt, U., Engel, A., and Müller, M.: Ozone loss derived from balloon-borne tracer measurements in the 1999/2000 Arctic winter, Atmos. Chem. Phys., 5, 1423-1436, 2005, http://www.atmos-chem-phys.net/5/1423/2005/.

Ross, D. E. M., Pyle, J. A., Harris, N. R. P., McIntyre, J. D., Millard, G. A., Robinson, A. D., and Busen, R.: Investigation of Arctic ozone depletion sampled over midlatitudes during the Egrett campaign of spring/summer 2000, Atmos. Chem. Phys., 4, 1407-1417, 2004, http://www.atmos-chem-phys.net/4/1407/2004/.

Saiz-Lopez, A., Mahajan, A. S., Salmon, R. A., Bauguitte, S. J.-B, Jones, A. E., Roscoe, H. K., and Plane, J. M. C.: Boundary Layer Halogens in Coastal Antarctica, Science, 317, 348-351, 2007.

Salawitch, R. J.: Biogenic bromine, Nature, 439, 275-277, 2006.

Sander, R., Keene, W. C., Pszenny, A. A. P., Arimoto, R., Ayers, G. P., Baboukas, E., Cainey, J. M., Crutzen, P. J., Duce, R. A., Hönninger, G., Huebert, B. J., Maenhaut, W., Mihalopoulos, N., Turekian, V. C., and Van Dingenen, R.: Inorganic bromine in the marine boundary layer: a critical review, Atmos. Chem. Phys., 3, 1301-1336, 2003,

http://www.atmos-chem-phys.net/3/1301/2003/.
Savage, N. H., Law, K. S., Pyle, J. A., Richter, A., Nüß, H., and Burrows, J. P.: Using GOME $\mathrm{NO}_{2}$ satellite data to examine regional differences in TOMCAT model performance, Atmos. Chem. Phys., 4, 1895-1912, 2004, http://www.atmos-chem-phys.net/4/1895/2004/.

Schall, C., Heumann, K. G., and Kirst, G. O.: Biogenic volatile organoiodine and organobromine hydrocarbons in the Atlantic Ocean from $42^{\circ} \mathrm{N}$ to $72^{\circ} \mathrm{S}$, Fresen. J. Anal. Chem., 359, 298305, 1997.

Tokarczyk, R. and Moore, R. M.: Production of volatile organohalogens by phytoplankton cultures, Geophys. Res. Lett, 21(4), 285-288, 1994.

von Glasow, R., von Kuhlmann, R., Lawrence, M. G., Platt, U., and Crutzen, P. J.: Impact of reactive bromine chemistry in the troposphere, Atmos. Chem. Phys., 4, 2481-2497, 2004, http://www.atmos-chem-phys.net/4/2481/2004/.

Warwick, N. J., Pyle, J. A., Carver, G. D., Yang, X., Savage, N. H., O'Connor, F. M., and Cox, R. A.: Global modeling of biogenic bromocarbons, J. Geophys. Res., 111, D24305, doi:10.1029/2006JD007264, 2006.

World Meteorological Organisation (WMO): Scientific Assessment of Ozone Depletion: Global ozone research and monitoring project, Rep. 47, World Meteorol. Org., Geneva, 2003.

World Meterological Organisation (WMO): Scientific Assessment of Ozone Depletion 2006: Global ozone research and monitoring project, Rep. 50, World Meteorol. Org., Geneva, 2007.

Yang, X., Cox, R. A., Warwick, N. J., Pyle, J. A., Carver, G. D., O'Connor, F. M., and Savage, N. H.: Tropospheric bromine chemistry and its impacts on ozone: A model study, J. Geophys. Res., 110, D23311, doi:10.1029/2005JD006244, 2005.

Yang, X., Pyle, J. A., and Cox, R. A.: Sea salt aerosol production and bromine release: Role of snow on sea ice, Geophys. Res. Lett., 35, L16815, doi:10.1029/2008GL034536, 2008.

Yang, X., Pyle, J. A., and Cox, R. A.: Blowing snow on sea ice, polar explosions and global ozone, Atmos. Chem. Phys. Discuss., to be submitted, 2009.

Yokouchi, Y., Hasebe, F., Fujiwara, M., Takashima, H., Shiotani, M., Nishi, N., Kanaya, Y., Hashimoto, S., Fraser, P., ToomSauntry, D., Mukai, H., and Nojiri, Y.: Correlations and emission ratios among bromoform, dibromochloromethane, and dibromomethane in the atmosphere, J. Geophys. Res., 110, D23309, doi:10.1029/2005JD006303, 2005. 